Article

\title{
Analysis of Proteomic Profile of Contrasting Phosphorus Responsive Rice Cultivars Grown under Phosphorus Deficiency
}

\author{
Aadil Yousuf Tantray ${ }^{1}$, Hayssam M. Ali ${ }^{2}$ and Altaf Ahmad ${ }^{1, *(\mathbb{D}}$ \\ 1 Department of Botany, Aligarh Muslim University, Aligarh 202002, India; tantray.rs@amu.ac.in \\ 2 Botany and Microbiology Department, College of Science, King Saud University, P.O. Box. 2455, \\ Riyadh 11451, Saudi Arabia; hayhassan@ksu.edu.sa \\ * Correspondence: aahmad.bo@amu.ac.in
}

Received: 15 June 2020; Accepted: 14 July 2020; Published: 16 July 2020

check for updates

\begin{abstract}
Phosphorus (P) deficiency is one of the major limiting factors for crop productivity. The yield of rice (Oryza sativa L.) is severely limited by phosphorus deficiency. An attempt has been made in this study to identify $\mathrm{P}$ deficiency responsive differentially expressed proteins of rice through analysis of leaf proteome of contrasting P-responsive rice cultivars under P deficiency conditions because genetic variability has been found in the rice cultivars for adaptive response to $\mathrm{P}$ deficiency and a controlled regulatory system is involved in the $\mathrm{P}$ deficiency adaptation response. Phosphorus-efficient (cv. Panvel) and P-inefficient (cv. Nagina 22) rice cultivars were hydroponically grown in the nutrient medium under control environmental conditions at low-P level $(2.0 \mu \mathrm{M})$ and optimum-P level $(320 \mu \mathrm{M})$ treatments. Expression patterns of the proteins of the leaves of both the cultivars were analyzed in 30-day-old plants. The identification of these proteins through mass spectrometry and MASCOT software (Matrix Science Inc., Boston, USA) revealed that these differentially expressed proteins were homologous to known functional proteins involved in energy metabolism, biosynthesis, photosynthesis, signaling, protein synthesis, protein folding, phospholipid metabolism, oxidative stress, transcription factors, and phosphorus metabolism. It has been observed that rice cultivars responded differently to low-P treatment through modification in protein expressions pattern to maintain the growth of the plants. Therefore, the expression patterns of proteins were different in both of the cultivars under low-P treatment. Higher potential of protein stability, stress tolerance, osmo-protection, and regulation of phosphorus uptake was observed in cv. Panvel than cv. Nagina 22. This study could help to unravel the complex regulatory process that is involved in adaptation to $P$ deficiency in rice.
\end{abstract}

Keywords: phosphorus use efficiency; phosphorus; proteomics; rice

\section{Introduction}

The food crisis in developing countries is due to a decrease in crop productivity, on the one hand, and increased the global human population, on the other side [1]. Phosphorus (P) is macro-nutrients and an essential component of phospholipids, proteins, and nucleotide-containing molecules, like RNA and DNA. It is one of the major limiting factors that influence crop production. Estimation shows that almost $50 \%$ of the world's agricultural lands are P-deficient [2]. Phosphorus fertilizers are applied in the agricultural field in order to overcome this deficiency and maintain crop production. However, the phosphorus use efficiency (PUE) of crop plants is only 10-20\% [3]. This low PUE has increased the global demand of $P$ fertilizers that reached 47 million tonnes [4] and created severe environmental problems. like eutrophication, because of unutilized $\mathrm{P}$ in the agricultural field. Because the only 
sources of $\mathrm{P}$ fertilizers are phosphate rocks, and the accessibility of phosphate rocks is estimated to last in the next 300-400 years according to the International Fertilizer Development Centre [5], the improvement in the P efficiency of crop plants would be an important contribution to the sustainability of agroecosystems.

Rice is a staple food for more than $50 \%$ of the world's population [6]. It has been found that there is a gradual decline in rice productivity. Estimations show that it will reach $40 \%$ of the present productivity by the end of the 21st century [7]. P deficiency is one of the reasons for the decline in the production of rice. Plants respond to $\mathrm{P}$ deficiency stress at morphological, physiological, and molecular levels. Leaf growth inhibition in response to low-P supply has been reported that results in the reduction of plant growth [8]. Phosphorus deficiency affected many metabolic processes that led to a decrease in the biomass accumulation and overall growth of the plants. A decrease in the photosynthesis of rice by $\mathrm{P}$ deficiency has been observed through the reduction in the activities of the enzyme of the Calvin cycle [9]. It has been reported that the sufficient supply of $P$ improved the activities of sucrose phosphate synthase, glutamine synthase, and PEP carboxylase in leaves of rice [10]. The exposure of plants to stresses leads to the identification of stress-responsive genes, numerous downstream effectors, and signaling factors/components through analysis of the expression profiling of genes. It is suggested that there is a well sophisticated regulatory network of genes in plants to access and control the nutrient homeostasis [11-15]. Therefore, there is a need to explore the research on the identification of the regulatory gene(s) of rice that are involved in the mechanism of P-deficiency tolerance. Kim et al. [16] have shown that proteins that are involved in the metabolism and defense/stress response, like putative glyceraldehydes-3-phosphate dehydrogenase, S-adenosyl-L-methionine synthetase, ATP synthase subunit alpha, and root-specific pathogenesis-related protein ten, were differentially regulated in the roots of rice under P-starvation. In another study on rice, proteins that are involved in signal transduction and plant defense responses, like abscisic ASR1, superoxide dismutase, glutathione S-transferase, salt stress-induced proteins, and putative r40c1 protein, were found to be differentially expressed under P-starvation conditions [17]. These studies are primarily limited to the proteome profiling of the roots of rice under P-starvation conditions and have not provided information about the proteome profiling in leaves. Since the leaves are the sites of assimilation and utilization of $P$, the present study was conducted to study the leaf proteome profiling of P-efficient and P-inefficient cultivars of rice to identify differential expression of P-starvation responsive proteins, and to determine the mechanism of rice adaptation to P-starvation. A basis of investigation of the function and regulation of protein involved in low-P tolerance will be provided by this study in order to help develop rice with high PUE through genetic manipulation.

\section{Materials and Methods}

\subsection{Plant Material and Growth Conditions}

Seeds of P-inefficient (cv. Nagina 22) and P-efficient (cv. Panvel) rice cultivars were obtained from the Indian Agricultural Research Institute, New Delhi, India. The cv. Nagina 22 is tall, susceptible to blast, resistant to drought, and cultivated in the Uttar Pradesh state of India. The grains of this variety are short, bold, and white. The yield is $20-25 \mathrm{Q} / \mathrm{ha}$. The cv. Panvel is semi-dwarf, resistant to neck blast, and cultivated in the Maharashtra state of India. The grains are short, bold, and yield is $40-43 \mathrm{Q} / \mathrm{ha}$. The cv. Nagina 22 is an Aus-type and cv. Panvel is an Indica subspecies. The seeds of cv. Nagina 22 and cv. Panvel rice cultivars were surface sterilized with $75 \%$ alcohol and $0.1 \%$ mercuric chloride for $5 \mathrm{~min}$ and thoroughly rinsed four times with distilled water. Sterilized seeds were germinated in distilled water for six days in a hydroponic culture system $(90$ seedlings in $5 \mathrm{~L}$ tank). After six days, the distilled water was replaced by Yoshida nutrient solution without $\mathrm{P}$. The $\mathrm{P}$ was supplied in the form of phosphoric acid $\left(\mathrm{H}_{3} \mathrm{PO}_{4}\right)$ with two concentrations, i.e., low $(2 \mu \mathrm{M})$ and optimum (320 $\mu \mathrm{M}$, according to Yoshida) [18]. Each treatment consisted of three replications. The medium was replaced after every three days and properly aerated with an aquarium air-filter pump 
(aerated solution increases $\mathrm{P}$ accumulation in root and shoot [19]), and $\mathrm{pH}$ was maintained at $5.6 \pm 0.2$. The experiment was conducted in controlled conditions of a plant growth chamber, 14:10 h light/dark period, the relative humidity of $60 \%, 28 / 22{ }^{\circ} \mathrm{C}$ day/night temperature, and a photosynthetic photon flux density of $430 \mu \mathrm{mol} \mathrm{m} \mathrm{m}^{-2} \mathrm{~s}^{-1}$. The initiation of primary tillering in rice starts from the fourth week after sowing. Top leaf samples (third and fourth leaf) were collected with three biological and three technical replicates after 30 days of sowing (Figure S1). For proteomic analysis, the sampled leaves were frozen in liquid nitrogen before their storage at $-80^{\circ} \mathrm{C}$. Morphological parameters, such as length, fresh weight and dry weight of shoot and root, and phosphorus content of leaf and root, were measured. Shoot and root length were measured while using a measuring scale and represented in centimeter $(\mathrm{cm})$. The phosphorus content of leaf and root samples was measured by digesting samples in a di-acid mixture $\left(\mathrm{HNO}_{3}: \mathrm{HClO}_{4}=9: 4 \mathrm{v} / \mathrm{v}\right)$ and spectrophotometrically determined at $625 \mathrm{~nm}$ after adding using vanadate-molybdate reagent [20]. The fresh weight of shoot and root samples were measured at the time of harvesting, and the dry weights were measured after drying the shoot and root samples in an oven at $65^{\circ} \mathrm{C}$ for $72 \mathrm{~h}$ and represented as g plant ${ }^{-1}$. The PUE was calculated using Syers et al. [21] formula, the total $\mathrm{P}$ uptake divided by the amount of $\mathrm{P}$ applied and multiplied by 100 .

\subsection{Protein Extraction}

The stored leaves were used for protein extraction by the modified phenol method of Isaacson et al. [22]. Fine powder of two grams of leaf material was prepared in liquid nitrogen and homogenized in $10 \mathrm{~mL}$ extraction buffer $(700 \mathrm{mM}$ sucrose, $50 \mathrm{mM}$ HEPES, $100 \mathrm{mM} \mathrm{KCl}, 50 \mathrm{mM}$ EDTA, and $2 \%$ SDS), with pH 7.5 and on homogenizing, $2 \% \beta$-mercaptoethanol and $1 \mathrm{mM}$ PMSF were also added. Then $15 \mathrm{~mL}$ of molecular grade phenol (Sigma-Aldrich, St. Louis, Missouri, USA) was added, and the solution was mixed for $30 \mathrm{~min}$ on ice-rocker and centrifugation at $3200 \times g$ for $10 \mathrm{~min}$ at $4{ }^{\circ} \mathrm{C}$ to recovered top phenolic layer. The protein was precipitated in ice-cold $0.1 \mathrm{M}$ ammonium acetate solution at $-20^{\circ} \mathrm{C}$ overnight. The protein pellet was collected by centrifugation at $6500 \times g$ $\left(15 \mathrm{~min}\right.$ at $\left.4{ }^{\circ} \mathrm{C}\right)$ and then washed two times with cold acetone at the same speed and then lyophilized (Labconco, Kansas City, USA) at $-50^{\circ} \mathrm{C}$. The pellet was solubilized in a cocktail buffer $(7 \mathrm{M}$ urea, $2 \mathrm{M}$ thiourea, $50 \mathrm{mM}$ DTT, and 4\% 3-[(3-cholamidopropyl) dimethylammonio]-1-propanesulfonate). Using a 2D Quant Kit (GE Healthcare, Munich, Germany), protein concentration was estimated with bovine serum albumin (BSA) used as a reference.

\subsection{Two-Dimensional Gel Electrophoresis}

Bio-Rad's apparatus and chemical grades were used for two-dimensional electrophoresis (2-DE) and performed by the method of $\mathrm{O}^{\prime}$ Farrell [23]. An immobilized dry strip gel $(11 \mathrm{~cm}$, linear-gradient, $\mathrm{pH}$ 4-7; Bio-Rad, Hercules, California, USA) was rehydrated at $20^{\circ} \mathrm{C}$ for $12 \mathrm{~h}$ in $180 \mu \mathrm{L}$ of a sample containing $350 \mu \mathrm{g}$ proteins. The first dimension, i.e., isoelectric focusing was carried on the following program; $250 \mathrm{~V}$ for $30 \mathrm{~min}, 500 \mathrm{~V}$ for $30 \mathrm{~min}, 1000 \mathrm{~V}$ for $1 \mathrm{~h}, 2000 \mathrm{~V}$ for $1 \mathrm{~h}$ followed by a linear increase of $6000 \mathrm{~V}$ to a total of $65.00 \mathrm{kV}$, and completed in $16: 30 \mathrm{~h}$. The strips were then subjected to reduction by equilibration buffer (containing $8 \mathrm{M}$ urea, 20\% glycerol, $50 \mathrm{mM}$ Tris, $2 \%$ SDS, and $130 \mathrm{mM}$ DTT) at pH 8.8 and, followed by alkylation using same equilibration buffer with $135 \mathrm{mM}$ iodoacetamide instead of DTT. The second dimension, SDS-PAGE was carried out for the separation of proteins, using $12 \%$ SDS in large vertical format electrophoresis cell (PROTEAN ${ }^{\circledR}$ II Xi Cell, Bio-Rad, Hercules, California, USA) at a constant voltage of $150 \mathrm{~V}$. The gels were stained overnight with Coomassie Brilliant Blue G-250 dye and then destained with sterilized MilliQ water (Milli- ${ }^{\circledR}$, Merck KGaA, Darmstadt, Germany) by washing several times.

\subsection{Gel Analysis}

Digital imaging of the gel was captured by the gel documentation system (GS-900 ${ }^{\mathrm{TM}}$ Calibrated Densitometer, Bio-Rad, Hercules, California, USA) for further analysis of set parameters (relative abundance, spot density, and location by comparing $\mathrm{pH}$ and mass). The image master PDQuest 
software (version 8.0, Bio-Rad, Hercules, California, USA) was used for gel image analysis. Optimized parameters were considered as partial threshold 4, saliency 2.0, and minimum area 50. Each spot was normalized with the total volume percentage of all of the spots for rectification of unevenness due to quantitative diversity in spot intensities. The quantification of spots was held based on their relative volume and quality, which was concluded by the ratio of the single spot volume to the whole comparative set of the spots.

\subsection{In-Gel Digestion and MALDI-TOF/TOF-MS Analysis}

Differential responsive protein spots were excised from the gels and, to remove the excess SDS, the gels were washed three times with sterilized MilliQ water. Destaining of excised gel pieces was done using $50 \mathrm{mM}$ ammonium bicarbonate and dehydrated with $100 \%$ acetonitrile (ACN). $15 \mathrm{mM}$ DTT was used for the reduction of dehydrated protein spots at $60^{\circ} \mathrm{C}$ for $1 \mathrm{~h}$, and protein spots were subjected to alkylation in the dark for $15 \mathrm{~min}$ by using $100 \mathrm{mM}$ iodoacetamide. Before drying in a speed vacuum, these protein spots were rehydrated with $50 \mathrm{mM}$ ammonium bicarbonate. Dried gel pieces were digested with $15 \mu \mathrm{L}$ of working trypsin $(10 \mathrm{ng} / \mu \mathrm{L})$ (Promega, Madison, Wisconsin, USA) overnight at $37^{\circ} \mathrm{C}$. The supernatant was taken in a fresh centrifuge tube, and 20:1 percentage of acetonitrile and the formic acid solution were added for further extraction of remaining gel pieces. To reduce the volume of the final supernatant to $25-50 \mu \mathrm{L}$, it was dried in a speed vacuum. The final volume was subjected to a mass spectrometer (Applied Biosystems SCIEX 4800 MALDI TOF/TOF ${ }^{\mathrm{TM}}$, Foster City, CA, USA), which was controlled by the 4000 Series Explorer ${ }^{\mathrm{TM}}$ software (Applied Biosystems, Foster City, CA, USA) using set parameters with the peptide charge of $1+$ and peptide tolerance of $150 \mathrm{ppm}$. A mass ranges from 800 to 4000 with a focus mass of 2000 was used to record the mass spectrometer (MS) spectra in reflector mode. The instrument was calibrated by a CalMix 5 standard (ABI 4700 Calibration Mixture, Foster City, CA, USA), and 25 sub-spectra with 125 shots per sub spectrum were amassed while using a random search pattern for each MS spectrum. Trypsin autolysis peaks were used for MS calibration, and MS/MS acquisition of precursors was selected up to 10 of the most intense ion signals, excluding the trypsin autolysis peaks and the matrix ion signals. For one main MS spectrum, $50 \mathrm{sub}$ spectra with 50 shots per sub-spectrum were accumulated in MS/MS positive ion mode, while using a random search pattern. Air was used as collision gas, $2 \mathrm{kV}$ collision energy, and Glu1-Fibrinopeptide B spotted onto the Cal 7 positions of the MALDI target were used as in default calibration.

\subsection{Protein Identification and Database Searching}

Following the calibration, the data were picked while using GPS Explorer (Applied Biosystems 2006, Foster City, CA, USA) for monoisotopic peak analysis, and the MASCOT program (http: //www.matrixscience.com) was used for analyzing the monoisotopic peak lists, but only significant peak hits with probability analysis $(p<0.05)$, were accepted. The peptides were searched with Protein-NCBI database [24] allowing for single trypsin missed cleavage, partial modification of cysteine carbamidomethylated, and methionine oxidized with the pyro-Glu formation of N-terminal. To achieve identification results with high confidence $(\geq 95 \%)$, the protein should have a valuable MOWSE (Molecular Weight Search) score, sequence coverage greater than $15 \%$, and at least six peptides matched. The functional information of identified proteins was assembled with the help of NCBI [24] and Uniprot [25] databases. The subcellular location of identified proteins was also assimilated by pTARGET [26] and Uniprot databases in order to understand the function of the identified proteins.

\subsection{Statistical Analysis}

In the present study, the statistical analysis of physiological traits was carried by two-ANOVA analysis, for each response, treatment and cultivars were selected as factors at $p<0.05$ (Minitab 17.0). The significance between treatments of each rice cultivar was determined at ${ }^{*} p<0.05,{ }^{* *} p<0.01$, and ${ }^{* * *} p<0.001$. The protein samples were taken in three biological and three technical replicates. For the normalization of protein, spots paired Student's $t$-test with the significance of $95 \%$ was performed, with 
the help of SPSS software (SPSS for Windows, Version 16.0. SPSS Inc., Chicago, IL, USA). The spots in analyzer manager with greater than two-fold change intensity in volume during the comparison or with significant variation between the control and other treatments decisive by the paired Student's $t$-test $(p \leq 0.05)$, were regarded as the treatment-responsive proteins. The protein spots with increased $>2$-fold charge intensity in volume at low-P treatment than optimum-P were considered to be up-regulated proteins. The protein spots with decreased $>2$-fold charge intensity in volume at low-P treatment than optimum-P were considered as down-regulated proteins.

\section{Results}

\subsection{Morphological Traits as Influenced by Low-P and Optimum-P Treatments}

The morphological traits, like the length of root and shoot, plant biomass, $\mathrm{P}$ concentration of leaf and root, and PUE of cv. Panvel and cv. Nagina 22, were measured under the treatments of low-P and optimum-P. All of the traits were significantly decreased under low P treatment, except root length, which significantly increased under low-P treatment in both of the cultivars as compared with the optimum-P treatment (Table 1). The increase in the root length was $23.24 \%$ and $16.34 \%$ in cv. Nagina 22 and cv. Panvel, respectively, under low P treatment, when compared with the optimum-P treatment. Low-P treatment reduced the shoot length of cv. Nagina 22 and cv. Panvel by $25.2 \%$ and $12.9 \%$, respectively, when compared with the optimum $P$ treatment. Plant dry weight was also reduced by low $\mathrm{P}$ treatment. However, the reduction of dry weight in both the cultivars varied. The percent reduction in the dry weight of the cv. Nagina 22 and cv. Panvel were $39.2 \%$ and $17.3 \%$, respectively. The plant dry weight of cv. Nagina 22 was low than cv. Panvel even at optimum-P. Phosphorus concentration of leaf and root was lesser in cv. Nagina 22 than cv. Panvel under both the treatments. Low P treatment decreased the concentration of the $\mathrm{P}$ also in both the cultivars. The decrease in $\mathrm{P}$ concentration was significantly more in cv. Nagina than cv. Panvel. The PUE of cv. Panvel was higher than cv. Nagina 22 at both the treatments of $P$.

Table 1. Morphological traits and phosphorus concentration and phosphorus use efficiency of cv. Nagina 22 and cv. Panvel rice under optimum-P and low-P treatments.

\begin{tabular}{cccccccc}
\hline \multirow{2}{*}{ Physiological Traits } & \multicolumn{2}{c}{ Cv. Nagina 22 } & \multicolumn{2}{c}{ Cv. Panvel } & \multicolumn{3}{c}{$\begin{array}{c}\text { Statistical Analysis } \\
(p<0.05)\end{array}$} \\
\cline { 2 - 7 } & Optimum-P & Low-P & Optimum-P & Low-P & C & T & C $\times$ T \\
\hline Root length (cm) & $14.2 \pm 2.55$ & $18.5 \pm 2.78^{* *}$ & $12.8 \pm 1.98$ & $15.3 \pm 1.67^{*}$ & 0.031 & 0.012 & 0.033 \\
$\begin{array}{c}\text { Shoot length (cm) } \\
\text { Plant dry weight } \\
\quad\left(\text { g plant }^{-1} \text { ) }\right.\end{array}$ & $32.5 \pm 3.66$ & $24.3 \pm 3.11^{*}$ & $36.4 \pm 4.23$ & $31.6 \pm 0.34^{*}$ & 0.033 & 0.021 & 0.035 \\
$\begin{array}{c}\text { Leaf P concentration } \\
\quad\left(\mathrm{mg} \mathrm{g}^{-1} \text { DW) }\right.\end{array}$ & $1.63 \pm 0.24$ & $1.04 \pm 0.21^{* * *}$ & $2.05 \pm 0.32$ & $1.57 \pm 0.22^{* *}$ & 0.013 & 0.003 & 0.007 \\
$\begin{array}{c}\text { Root P concentration } \\
\left(\mathrm{mg} \mathrm{g}^{-1} \text { DW) }\right.\end{array}$ & $1.78 \pm 0.23$ & $1.22 \pm 0.20^{* *}$ & $2.14 \pm 0.33$ & $1.72 \pm 0.25^{*}$ & 0.021 & 0.005 & 0.011 \\
$\begin{array}{c}\text { Phosphorus use } \\
\text { efficiency (\%) }\end{array}$ & $12.96 \pm 1.24$ & $8.61 \pm 1.03^{* *}$ & $15.97 \pm 2.01$ & $12.54 \pm 1.73^{*}$ & 0.002 & 0.000 & 0.006 \\
\hline
\end{tabular}

Data are represented as mean \pm standard error $(\mathrm{n}=3)$. The ANOVA analysis was carried at $p<0.05$ for cultivars $(C)$, treatments $(\mathrm{T})$, and their interaction $(\mathrm{C} \times \mathrm{T})$. The asterisks in the table represent the significance of the treatment in each cultivar at ${ }^{*} p<0.05, * * p<0.01$ and ${ }^{* * *} p<0.001$.

\subsection{Number of Differentially Expressed Proteins}

Figure 1 shows the distribution of protein spots in the proteomic maps of Nagina 22 and Panvel rice cultivars, grown under optimum-P and low-P conditions. The reproducible rate of protein spots was reasonable, and a total of 512 protein spots were detected in each gel. After analysis, 63 $(12.3 \%)$ protein spots were differentially expressed in rice cultivars at low-P treatment. Out of the 63 differentially expressed protein (DEP) spots, 42 (66.67\%) spots were up-regulated and $21(34.92 \%)$ spots were down-regulated (Table 2). In cv. Nagina 22, 21 proteins were up-regulated and 17 proteins were 
down-regulated at low-P treatment. The numbers of upregulated proteins were 35, and down-regulated proteins were 11 in cv. Panvel under the low-P treatment (Table 2). These results suggested that P-deficiency resulted in major changes in the leaf proteome of rice.

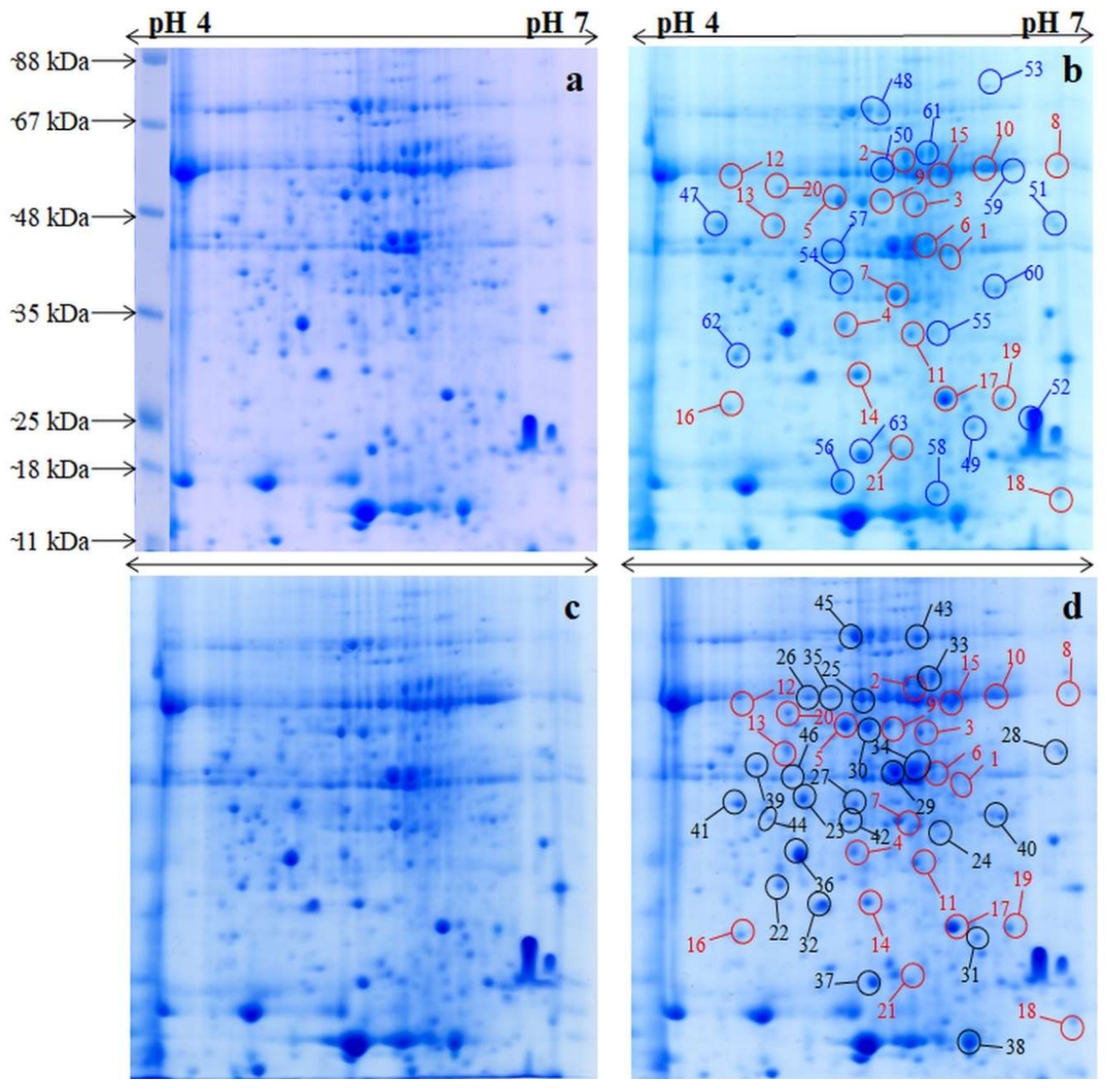

Figure 1. 2-DE gel maps of total leaf proteome of rice varieties. (a) cv. Nagina 22 under optimum-P condition; (b) cv. Nagina 22 under low-P condition; (c) cv. Panvel under optimum-P condition; (d) cv. Panvel under low-P condition. Differentially expressed proteins that were common in both cv. Nagina 22 and cv. Panvel under low-P condition are marked with red circle. The differentially expressed proteins of cv. Nagina 22 only under low-P condition are marked with blue circle. The differentially expressed proteins of cv. Panvel only under low-P condition are marked with are black circle.

Table 2. Number of differentially expressed proteins in rice cultivars under low phosphorus level. The expression pattern was compared with the optimum P level.

\begin{tabular}{ccccc}
\hline Distribution of DEPs & Cv. Panvel & Cv. Nagina 22 & Cv. Panvel + Cv. Nagina 22 & Total DEPs \\
\hline Up regulated & 21 & 7 & 14 & 42 \\
Down regulated & 4 & 10 & 7 & 21 \\
\hline
\end{tabular}

DEPs-differentially expressed proteins

\subsection{Spatial and Functional Categorization of Differentially Expressed Proteins}

The differentially expressed proteins were identified of different sub-cellular sites (Figure 2a). These belonged to chloroplast (36\%), ribosome (12\%), nucleus (16\%), mitochondrion (9\%), and cytosol 
$(19 \%)$. Some of the low range proteins belonged to the endoplasmic reticulum (1\%), cell wall (3\%), cell membrane $(2 \%)$, and peroxisome $(2 \%)$. According to the exhibited homology known function of the proteins, $59(93.65 \%)$ among the 63 identified proteins were justified, whereas the rest $4(6.35 \%)$ was unknown. Functional categorization of these differentially expressed proteins showed that these proteins belonged to eleven groups (Figure $2 b$ ), viz., metabolism $(10 \%)$, protein synthesis $(8 \%)$, transcription/signal transduction mechanisms $(14 \%)$, cell rescue/defense $(12 \%)$, photosynthesis $(16 \%)$, energy $(6 \%)$, cell cycle/transport (3\%), oxidative stress (14\%), protein fate/stabilization $(9 \%)$, and unclassified function $(8 \%)$.

\section{$\mathbf{a}$}
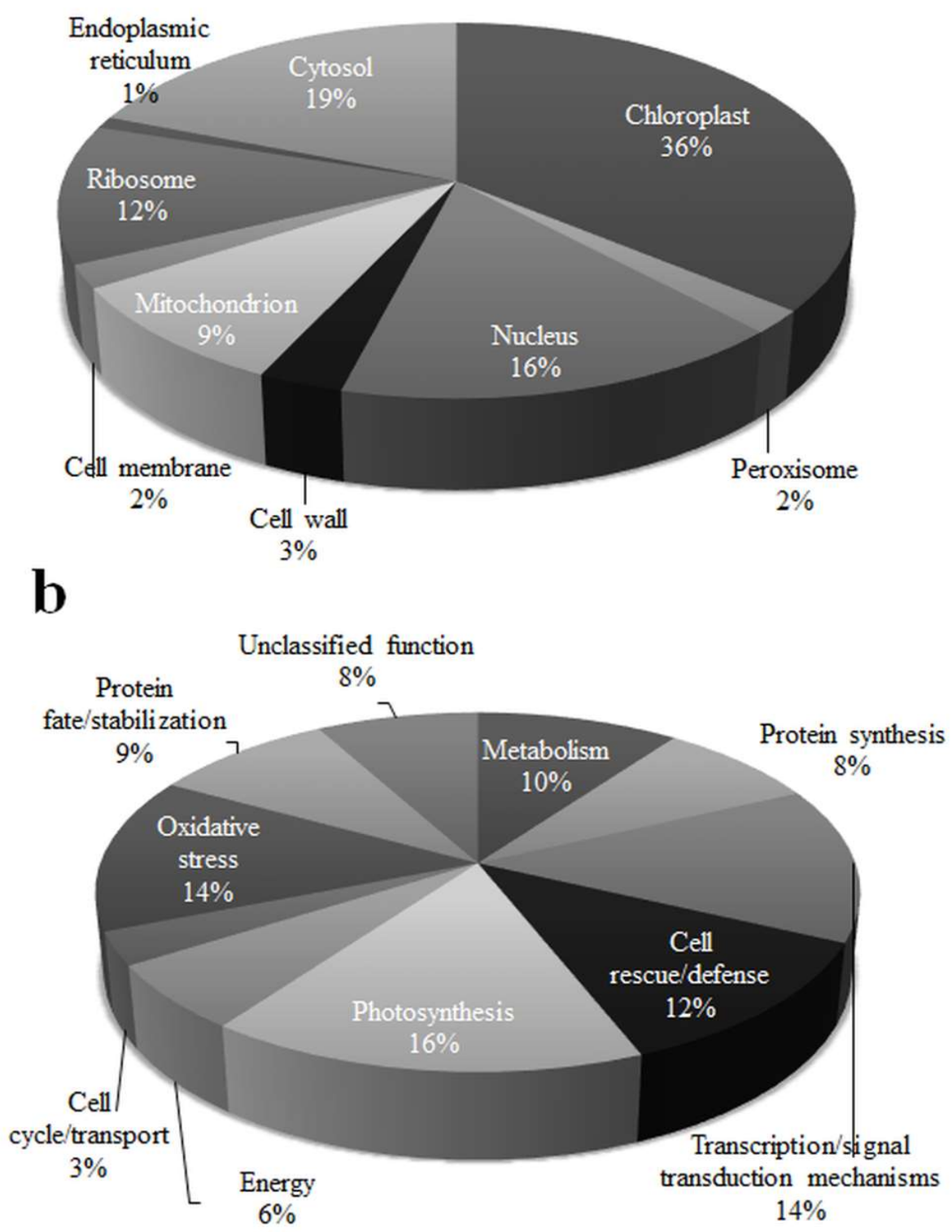

Figure 2. Percentage of spatial (a) and functional (b) distribution of differentially expressed proteins in rice leaf at low phosphorus conditions.

\subsection{Differentially Expressed Proteins of Rice Cultivars under Low P Condition}

The P-efficient (cv. Panvel) and P-inefficient (cv. Nagina) cultivars of rice both showed differential expression (up-regulation/down-regulation) of proteins under low $\mathrm{P}$ treatment when compared to optimum-P condition. While some differentially expressed proteins (DEPs) are common in both of the 
cultivars (Table 3), some DEPs are cultivar-specific (Tables 4 and 5). The identified upregulated and down-regulated proteins are described in the following sub-sections.

\subsubsection{Common Differentially Expressed Proteins of Cv. Nagina and Cv. Panvel under Low} P Condition

The expression patterns of twenty-one proteins of leaves was common in both the cultivars of rice under low $\mathrm{P}$ condition. Fourteen proteins were upregulated in both of the cultivars by low $\mathrm{P}$ treatment when compared to optimum P treatment (Table 3). However, the level of upregulation of these proteins differed in these rice cultivars. Similarly, the expressions of seven proteins were downregulated in both of the cultivars by low $\mathrm{P}$ treatment. However, the level of down-regulation differed in both of the cultivars. Fructose-bisphosphate aldolase was upregulated in both of the cultivars under low $\mathrm{P}$ treatment, when compared to the optimum $\mathrm{P}$ treatment. However, upregulation level was more in cv. Nagina than cv. Panvel. Maturase K, NADPH-dependent FMN reductase, ABA-responsive element-binding protein 3, methionine synthase, enolase 1 were identified as upregulated proteins in both of the cultivars at the same levels under low P treatment, when compared with optimum P treatment. The expression of succinate dehydrogenase flavoprotein subunit, glutathione S-transferase, photosystem II oxygen-evolving complex protein 1, glyoxylase I 7, chaperonin GroEL, DNA binding transcription factors, and protein disulfide isomerase were upregulated in both of the cultivars by low $\mathrm{P}$ treatment, but the markedly higher expression was found in cv. Panvel than cv. Nagina. Ribulose-1,5-bisphosphate carboxylase/oxygenase large subunit, NADP-dependent malate dehydrogenase, Small ribosomal protein 4, Ribulose-1,5-bisphosphate carboxylase/oxygenase small subunit, and Elongation factor Tu were identified as down-regulated proteins under low $\mathrm{P}$ treatment in both the cultivars. The level of down-regulation of Elongation factor Tu was higher in cv. Panvel than cv. Nagina. However, in all the other down-regulated proteins, the level of down-regulation was more in cv. Nagina than cv. Panvel (Table 3).

\subsubsection{Differentially Expressed Proteins of Cv. Panvel only under low P Condition}

Twenty-five proteins were differentially expressed in cv. Panvel only under low P condition, when compared to optimum P condition (Table 4). Out of these proteins, 21 were upregulated and four were down-regulated proteins. The upregulated proteins belonged to the category of photosynthesis (Phosphoribulokinase, NADP-dependent oxidoreductase P1), energy (chloroplastic Glyceraldehyde-3-phosphate dehydrogenase A, ATPase), metabolism (Succinyl-CoA synthetase beta subunit, 6-Phosphogluconolactonase, phosphogluconate dehydrogenase, inorganic pyrophosphatase family protein), protein synthesis (RNA-binding protein), protein stabilization (Chaperonin 60 $\beta$ precursor, Heat shock protein 40 , Heat shock responsive transcription factor), oxidative stress (59-epimerase, Flavonol synthase), signal transduction (14"C3 ${ }^{\circ} \mathrm{C} 3$ protein), and cell defence (Pyrroline-5-carboxylate synthetase). Down-regulated proteins belonged to the category of energy (Sedoheptulose-1,7-bisphosphatase), photosynthesis (Ribosomal protein S19), and metabolism (Malate dehydrogenase, pyruvate orthophosphate dikinase).

\subsubsection{Differentially Expressed Proteins of Cv. Nagina only under Low P Condition}

Seventeen proteins were differentially expressed in cv. Nagina under low P treatment, when compared with the optimum $P$ treatment (Table 5). Out of these proteins, seven proteins were upregulated and ten were down regulated under low P condition. The down-regulated proteins belong to the category of Photosynthesis (Rubisco activase chloroplast precursor, ferredoxin, light-harvesting complex I protein precursor LHCA3, chloroplastic Transketolase) and metabolism (Phosphoenolpyruvate carboxylase, Triosephosphate isomerase) and transcription/STMs (RNA polymerase $\beta$ chain, Integrin-linked protein kinase family protein). The upregulated proteins belonged to oxidative stress, protein stabilization, and energy. 
Table 3. Identification, subcellular localization, and quantitative analysis of differentially expressed leaf proteins of both the rice cultivars, cv. Nagina 22 and cv. Panvel, under low level of phosphorus.

\begin{tabular}{|c|c|c|c|c|c|c|c|c|c|c|c|}
\hline \multirow[t]{2}{*}{ S. N. } & \multirow[t]{2}{*}{ Accession No. } & \multirow[t]{2}{*}{ Name of Protein } & \multirow{2}{*}{$\begin{array}{l}\text { Exp. MW } \\
\text { (kDa) }\end{array}$} & \multirow[t]{2}{*}{ Exp. Pi } & \multirow[t]{2}{*}{ M.S. } & \multirow{2}{*}{$\begin{array}{l}\text { No. of } \\
\text { Matched } \\
\text { Peptides }\end{array}$} & \multirow[t]{2}{*}{ Location } & \multirow[t]{2}{*}{ Process } & \multirow{2}{*}{$\begin{array}{l}\text { Mode of } \\
\text { Regulation }\end{array}$} & \multicolumn{2}{|c|}{$\begin{array}{l}\text { Relative spot intensity } \\
\text { (Optimum P:Low P) }\end{array}$} \\
\hline & & & & & & & & & & Nagina 22 & Panvel \\
\hline 1 & ABL74560 & $\begin{array}{l}\text { Fructose-bisphosphate } \\
\text { aldolase }\end{array}$ & 45.6 & 6.45 & 82 & 12 & Cytosol & Energy & Upregulated & 1.00:3.13 & 1.00:2.91 \\
\hline 2 & XP_015646992 & $\begin{array}{l}\text { Succinate dehydrogenase } \\
\text { flavoprotein subunit }\end{array}$ & 65.8 & 6.12 & 134 & 15 & Mitochondrion & Energy & Upregulated & $1.00: 3.22$ & $1.00: 3.50$ \\
\hline 3 & BAA00147 & $\begin{array}{c}\text { Ribulose-1,5-bisphosphate } \\
\text { carboxylase/oxygenase } \\
\text { large subunit }\end{array}$ & 54.1 & 6.31 & 348 & 15 & Chloroplast & Photosynthesis & Downregulated & 1.00: -3.51 & 1.00: -3.23 \\
\hline 4 & AAS93256 & Glutathione S-transferase & 34.2 & 5.49 & 94 & 11 & Cytoplasm & Oxidative stress & Upregulated & $1.00: 2.40$ & $1.00: 2.91$ \\
\hline 5 & XP_015643741 & Enolase 1 & 57.8 & 5.59 & 107 & 11 & Chloroplast & $\begin{array}{c}\text { Cell } \\
\text { rescue/defense }\end{array}$ & Upregulated & 1.00:3.00 & 1.00:3.02 \\
\hline 6 & BAT16624 & $\begin{array}{l}\text { NADP-dependant malate } \\
\text { dehydrogenase }\end{array}$ & 49.3 & 6.14 & 114 & 13 & $\begin{array}{c}\text { Mitochondrion, } \\
\text { chloroplast, cytosol }\end{array}$ & Metabolism & Downregulated & 1.00: -3.32 & 1.00: -3.10 \\
\hline 7 & 2002393A & $\begin{array}{c}\text { Photosystem II } \\
\text { oxygen-evolving complex } \\
\text { protein } 1\end{array}$ & 37.2 & 6.87 & 159 & 13 & Chloroplast & Photosynthesis & Upregulated & $1.00: 2.54$ & $1.00: 3.00$ \\
\hline 8 & BAV53208 & Small ribosomal protein 4 & 53.2 & 6.93 & 89 & 9 & $\begin{array}{l}\text { Ribosome, } \\
\text { mitochondrion }\end{array}$ & Protein synthesis & Downregulated & $1.00:-3.43$ & 1.00: -3.11 \\
\hline 9 & AEP20544 & $\begin{array}{c}\text { Ribulose-1,5-bisphosphate } \\
\text { carboxylase/oxygenase } \\
\text { small subunit }\end{array}$ & 53.3 & 6.19 & 96 & 11 & Chloroplast & Photosynthesis & Downregulated & 1.00: -4.35 & 1.00: -3.72 \\
\hline 10 & AAP12937 & $\begin{array}{l}\text { Transposon protein, } \\
\text { putative, CACTA, } \\
\text { En/Spmsub-class }\end{array}$ & 56.2 & 6.8 & 86 & 16 & Nucleus & - & Upregulated & $1.00: 2.97$ & $1.00: 3.68$ \\
\hline 11 & Q948T6 & Glyoxylase I 7 & 33.4 & 6.3 & 86 & 14 & Peroxisome & Oxidative stress & Upregulated & $1.00: 4.20$ & $1.00: 5.20$ \\
\hline 12 & ABR25753 & Chaperonin GroEL & 65.3 & 4.91 & 87 & 10 & Cytoplasm & $\begin{array}{c}\text { Protein } \\
\text { fate/stabilization }\end{array}$ & Upregulated & $1.00: 3.53$ & 1.00:5.11 \\
\hline 13 & AAM74563 & Elongation factor $\mathrm{Tu}$ & 52.1 & 4.98 & 123 & 16 & $\begin{array}{l}\text { Cytosol, plastid, } \\
\text { mitochondrion }\end{array}$ & Protein synthesis & Downregulated & 1.00: -2.33 & 1.00: -2.72 \\
\hline 14 & NP_973937 & $\begin{array}{c}\text { DNA binding } \\
\text { transcription factors }\end{array}$ & 27.8 & 5.7 & 96 & 8 & Nucleus & Transcription/STMs & Upregulated & $1.00: 3.22$ & 1.00:4.61 \\
\hline 15 & Q2QLY4 & Methionine synthase & 55.1 & 6.5 & 112 & 10 & Cytosol & Metabolism & Upregulated & 1.00:4.21 & 1.00:4.52 \\
\hline 16 & CAD41255 & OSJNBa0067K08.7 & 33.4 & 5.33 & 141 & 8 & - & - & Downregulated & 1.00: -3.84 & 1.00: -3.51 \\
\hline 17 & D7LVK3 & $\begin{array}{l}\text { ABA-responsive element } \\
\text { binding protein } 3\end{array}$ & 32.8 & 5.93 & 123 & 11 & Nucleus & Transcription/STMs & Upregulated & 1.00:4.42 & 1.00:4.61 \\
\hline
\end{tabular}


Table 3. Cont.

\begin{tabular}{|c|c|c|c|c|c|c|c|c|c|c|c|}
\hline \multirow[t]{2}{*}{ S. N. } & \multirow[t]{2}{*}{ Accession No. } & \multirow[t]{2}{*}{ Name of Protein } & \multirow[t]{2}{*}{$\begin{array}{c}\text { Exp. MW } \\
\text { (kDa) }\end{array}$} & \multirow[t]{2}{*}{ Exp. Pi } & \multirow[t]{2}{*}{ M.S. } & \multirow{2}{*}{$\begin{array}{l}\text { No. of } \\
\text { Matched } \\
\text { Peptides }\end{array}$} & \multirow[t]{2}{*}{ Location } & \multirow[t]{2}{*}{ Process } & \multirow[t]{2}{*}{$\begin{array}{l}\text { Mode of } \\
\text { Regulation }\end{array}$} & \multicolumn{2}{|c|}{$\begin{array}{l}\text { Relative spot intensity } \\
\text { (Optimum P:Low P) }\end{array}$} \\
\hline & & & & & & & & & & Nagina 22 & Panvel \\
\hline 18 & P69667 & Ribosomal protein L23 & 10.13 & 7.02 & 81 & 8 & Mitochondrion & Protein synthesis & Downregulated & 1.00: -2.11 & 1.00: -2.02 \\
\hline 19 & Q6NPS8 & $\begin{array}{l}\text { NADPH-dependent FMN } \\
\text { reductase }\end{array}$ & 32.1 & 6.55 & 82 & 8 & Nucleus, cytoplasm & $\begin{array}{c}\text { Cell } \\
\text { cycle/transport }\end{array}$ & Upregulated & $1.00: 3.62$ & $1.00: 3.64$ \\
\hline 20 & AAX85991 & $\begin{array}{l}\text { Protein disulfide } \\
\text { isomerase }\end{array}$ & 57.1 & 5.3 & 152 & 6 & $\begin{array}{l}\text { Endoplasmic } \\
\text { reticulum }\end{array}$ & $\begin{array}{c}\text { Protein } \\
\text { fate/stabilization }\end{array}$ & Upregulated & $1.00: 2.71$ & $1.00: 3.22$ \\
\hline 21 & ANG44638 & Maturase K & 20.9 & 6.36 & 87 & 7 & Nucleus & $\begin{array}{c}\text { Cell } \\
\text { rescue/defense }\end{array}$ & Upregulated & $1.00: 4.84$ & $1.00: 4.80$ \\
\hline
\end{tabular}

S.N. = Spot number, Exp. Mw = Experimental molecular weight; Exp. Pi = Experimental isoelectric point; M.S. = Mascot score. PDQuest software was used for spot volume analysis. The fold change of up-regulated protein spot volumes was calculated by treatment/optimum, whereas the change fold of downregulated protein spot volumes was calculated by optimum/treatment. The relative spot intensity of proteins was shown in fold changes between optimum-P and low-P. Kd = Kilo-Dolton; STMs = Signal transduction mechanisms.

Table 4. Identification, sub-cellular localization, and quantitative analysis of differentially expressed leaf proteins of cv. Panvel only under low P condition.

\begin{tabular}{|c|c|c|c|c|c|c|c|c|c|c|}
\hline S. $N$. & Accession No. & Name of Protein & $\begin{array}{l}\text { Exp. Mw } \\
\text { (kDa) }\end{array}$ & Exp. Pi & M. S. & $\begin{array}{l}\text { No. of Matched } \\
\text { Peptides }\end{array}$ & Location & Process & $\begin{array}{c}\text { Mode of } \\
\text { Regulation }\end{array}$ & $\begin{array}{c}\text { Relative Spot } \\
\text { Intensity (Optimum } \\
\text { P: Low P) } \\
\end{array}$ \\
\hline 22 & ACA50522 & $14 " \mathrm{C} 3{ }^{\prime \prime} \mathrm{C} 3$ protein & 34.2 & 4.93 & 112 & 9 & Nucleus & Transcription/STMs & Upregulated & $1.00: 3.60$ \\
\hline 23 & BAD07865 & Phosphoribulokinase & 46.1 & 5.45 & 91 & 14 & Chloroplast, cytosol & Photosynthesis & Upregulated & $1.00: 3.22$ \\
\hline 24 & Q0DYB1 & $\begin{array}{l}\text { Inorganic pyrophosphatase } \\
\text { family protein }\end{array}$ & 33.2 & 6.1 & 110 & 12 & Cytoplasm & Metabolism & Upregulated & $1.00: 4.63$ \\
\hline 25 & BAD67774 & $\begin{array}{c}\text { Phosphogluconate } \\
\text { dehydrogenase }\end{array}$ & 54.2 & 5.89 & 104 & 14 & Cytoplasm & Metabolism & Upregulated & $1.00: 2.92$ \\
\hline 26 & BAF92702 & Chaperonin $60 \beta$ precursor & 55.1 & 5.4 & 128 & 8 & Mitochondrion & $\begin{array}{c}\text { Protein } \\
\text { fate/stabilization }\end{array}$ & Upregulated & 1.00:2.51 \\
\hline 27 & AAB33001 & Sedoheptulose-1,7-bisphosphatase & 41.9 & 5.81 & 143 & 14 & Chloroplast & Metabolism & Downregulated & 1.00: -2.11 \\
\hline 28 & 3E5R_A & $\begin{array}{l}\text { Glyceraldehyde-3-phosphate } \\
\text { dehydrogenase A, chloroplastic } \\
\text { precursor }\end{array}$ & 55.2 & 6.47 & 94 & 13 & Chloroplast & Energy & Upregulated & 1.00:3.52 \\
\hline
\end{tabular}


Table 4. Cont

\begin{tabular}{|c|c|c|c|c|c|c|c|c|c|c|}
\hline S. N. & Accession No. & Name of Protein & $\begin{array}{l}\text { Exp. Mw } \\
\text { (kDa) }\end{array}$ & Exp. Pi & M. S. & $\begin{array}{l}\text { No. of Matched } \\
\text { Peptides }\end{array}$ & Location & Process & $\begin{array}{c}\text { Mode of } \\
\text { Regulation }\end{array}$ & $\begin{array}{c}\text { Relative Spot } \\
\text { Intensity (Optimum } \\
\text { P: Low P) }\end{array}$ \\
\hline 29 & ABA18619 & 59-epimerase & 43.5 & 5.89 & 104 & 8 & Cytosol & Oxidative stress & Upregulated & $1.00: 3.23$ \\
\hline 30 & BAG24017 & RNA-binding protein & 49.7 & 5.30 & 106 & 9 & Cytosol, nucleus & Transcription/STMs & Upregulated & $1.00: 4.50$ \\
\hline 31 & M1NZ56 & $\begin{array}{l}\text { Pyrroline-5-carboxylate } \\
\text { synthetase }\end{array}$ & 28.1 & 6.7 & 114 & 13 & Cytoplasm & Cell rescue/defense & Upregulated & 1.00:3.11 \\
\hline 32 & ACJ54888 & Heat shock protein 40 & 28.7 & 5.8 & 96 & 8 & $\begin{array}{c}\text { Nucleus, } \\
\text { mitochondrion, ER }\end{array}$ & $\begin{array}{c}\text { Protein } \\
\text { fate/stabilization }\end{array}$ & Upregulated & $1.00: 3.50$ \\
\hline 33 & AAF85973 & PR-10b protein & 17.2 & 6.7 & 23 & 9 & Nucleus & - & Upregulated & $1.00: 2.55$ \\
\hline 34 & ABA39947 & UDP-glucose epimerase & 42.5 & 5.78 & 102 & 8 & Cytosol & Oxidative stress & Upregulated & $1.00: 1.63$ \\
\hline 35 & BAS78758 & Os02g0493300 & 56.4 & 6.15 & 87 & 8 & - & - & Upregulated & $1.00: 1.80$ \\
\hline 36 & AJB98433 & 6-Phosphogluconolactonase & 34.2 & 5.46 & 87 & 10 & Cytosol & Metabolism & Upregulated & 1.00:3.41 \\
\hline 37 & Q40693 & Heat shock protein 70 & 27.5 & 5.3 & 92 & 9 & $\begin{array}{c}\text { Nucleus, } \\
\text { mitochondrion }\end{array}$ & $\begin{array}{c}\text { Protein } \\
\text { fate/stabilization }\end{array}$ & Upregulated & $1.00: 1.50$ \\
\hline 38 & BAA11351 & Ribosomal protein S19 & 12.6 & 6.8 & 58 & 13 & $\begin{array}{c}\text { Ribosome, } \\
\text { mitochondrion }\end{array}$ & Protein synthesis & Downregulated & 1.00: -3.22 \\
\hline 39 & ABI74568 & Phosphoglycerate kinase & 46.2 & 5.48 & 167 & 14 & Cytosol & Energy & Upregulated & $1.00: 3.53$ \\
\hline 40 & ABA92415 & $\begin{array}{l}\text { NADP-dependent } \\
\text { oxidoreductase P1 }\end{array}$ & 40.3 & 6.31 & 119 & 13 & Chloroplast & Photosynthesis & Upregulated & $1.00: 3.28$ \\
\hline 41 & AAQ23061 & $\begin{array}{l}\text { Heat shock responsive } \\
\text { transcription factor }\end{array}$ & 37.9 & 5.1 & 54 & 9 & Nucleus, cytoplasm & $\begin{array}{c}\text { Protein } \\
\text { fate/stabilization }\end{array}$ & Upregulated & $1.00: 3.97$ \\
\hline 42 & BAC00625 & Malate dehydrogenase & 37.7 & 5.41 & 86 & 9 & Mitochondrion & Metabolism & Downregulated & 1.00: -3.24 \\
\hline 43 & AAK92626 & ATPase & 74.8 & 6.48 & 157 & 11 & Plasma membrane & Energy & Upregulated & $1.00: 3.32$ \\
\hline 44 & BAD17324 & Flavonol synthase & 35.9 & 5.43 & 104 & 10 & Cytoplasm, nucleus & Oxidative stress & Upregulated & 1.00:4.61 \\
\hline 45 & Q6AVA8 & $\begin{array}{l}\text { Pyruvate orthophosphate } \\
\text { dikinase }\end{array}$ & 73.3 & 5.15 & 128 & 22 & $\begin{array}{l}\text { Chloroplast, } \\
\text { cytoplasm }\end{array}$ & Metabolism & Downregulated & 1.00: -3.00 \\
\hline 46 & Q6K9N6 & $\begin{array}{l}\text { Succinyl-CoA synthetase beta } \\
\text { subunit }\end{array}$ & 44.2 & 5.64 & 63 & 10 & Mitochondrion & Metabolism & Upregulated & $1.00: 3.62$ \\
\hline
\end{tabular}

S.N. = Spot number, Exp. Mw = Experimental molecular weight; Exp. Pi = Experimental isoelectric point; M.S. = Mascot score. PDQuest software was used for spot volume analysis. The fold change of up-regulated protein spot volumes was calculated by treatment/optimum, whereas the change fold of downregulated protein spot volumes was calculated by optimum/treatment. The relative spot intensity of proteins was shown in fold changes between optimum-P and low-P. Kd = Kilo-Dolton; STMs = Signal transduction mechanisms. 
Table 5. Identification, subcellular localization, and quantitative analysis of differentially expressed leaf proteins of cultivar cv. Nagina 22 only under low P condition.

\begin{tabular}{|c|c|c|c|c|c|c|c|c|c|c|}
\hline S. N. & Accession No. & Name of Protein & $\begin{array}{c}\text { Exp. Mw } \\
\text { (kDa) }\end{array}$ & Exp. Pi & M. S. & $\begin{array}{l}\text { No. of Matched } \\
\text { Peptides }\end{array}$ & Location & Process & $\begin{array}{l}\text { Mode of } \\
\text { Regulation }\end{array}$ & $\begin{array}{c}\text { Relative Spot } \\
\text { Intensity (Optimum } \\
\text { P: Low P) } \\
\end{array}$ \\
\hline 47 & P93431 & $\begin{array}{l}\text { Rubisco activase chloroplast } \\
\text { precursor }\end{array}$ & 52.21 & 4.93 & 148 & 6 & Chloroplast & Photosynthesis & Downregulated & 1.00: -3.26 \\
\hline 48 & XP_015641702 & $\begin{array}{l}\text { Ferredoxin-nitrite reductase, } \\
\text { chloroplastic }\end{array}$ & 71.3 & 6.15 & 94 & 11 & Chloroplast & Photosynthesis & Downregulated & 1.00: -4.43 \\
\hline 49 & BAP76084 & $\begin{array}{l}\text { Phosphoenolpyruvate } \\
\text { carboxylase }\end{array}$ & 25.9 & 6.87 & 98 & 7 & $\begin{array}{l}\text { Chloroplast, } \\
\text { mitochondrion }\end{array}$ & Metabolism & Downregulated & 1.00: -3.26 \\
\hline 50 & Q01859 & F1-ATP synthase, beta subunit & 66.4 & 5.39 & 165 & 18 & Mitochondrion & Energy & Upregulated & $1.00: 4.70$ \\
\hline 51 & $\mathrm{~A} 3 \mathrm{C} 4 \mathrm{~S} 4$ & GDP-D-mannose-3', $5^{\prime}$-epimerase & 54.3 & 6.63 & 102 & 11 & Cytosol & Oxidative stress & Upregulated & $1.00: 3.32$ \\
\hline 52 & ABA96472 & $\begin{array}{l}\text { FKBP-type peptidyl-prolyl } \\
\text { cis-trans isomerase }\end{array}$ & 27.2 & 6.84 & 86 & 8 & Nucleus & Cell rescue/defense & Upregulated & $1.00: 3.83$ \\
\hline 53 & AAS46111 & RNA polymerase $\beta$ chain & 81.1 & 6.93 & 215 & 10 & Chloroplast & Transcription/STMs & Downregulated & 1.00: -3.90 \\
\hline 54 & AAB65699 & Ferredoxin & 44.5 & 6.35 & 147 & 16 & Chloroplast & Photosynthesis & Downregulated & 1.00: -3.44 \\
\hline 55 & A2Y7D9 & $\begin{array}{c}\text { Chloroplast light-harvesting } \\
\text { complex I protein LHCA3 }\end{array}$ & 31.1 & 6.46 & 85 & 7 & Chloroplast & Photosynthesis & Downregulated & 1.00: -3.37 \\
\hline 56 & P48494 & Triosephosphate isomerase & 21.2 & 5.5 & 151 & 13 & Cytoplasm & Metabolism & Downregulated & 1.00: -3.70 \\
\hline 57 & - & Unnamed protein product & 46.3 & 5.49 & 97 & 14 & - & - & Upregulated & $1.00: 3.80$ \\
\hline 58 & XP_015643207 & Transketolase chloroplastic & 17.8 & 6.12 & 84 & 16 & Chloroplast & Photosynthesis & Downregulated & 1.00: -3.52 \\
\hline 59 & ABL74559 & $\begin{array}{l}\text { Glyceraldehyde 3-phosphate } \\
\text { dehydrogenase }\end{array}$ & 53.8 & 6.72 & 84 & 8 & Cytoplasm & Energy & Upregulated & $1.00: 3.45$ \\
\hline 60 & AET04420 & $\begin{array}{l}\text { Integrin-linked protein kinase } \\
\text { family protein }\end{array}$ & 34.2 & 6.11 & 104 & 12 & Ribosome & Transcription/STMs & Downregulated & 1.00: -3.11 \\
\hline 61 & XP_015621402 & $\begin{array}{c}\text { Asparaginyl-tRNA synthetase, } \\
\text { cytoplasmic } 3\end{array}$ & 65.1 & 6.13 & 173 & 23 & Cytoplasm & Protein synthesis & Downregulated & 1.00: -3.24 \\
\hline 62 & AAP13093 & $\begin{array}{l}\text { Ascorbate peroxidase } \\
\text { cytoplasmic }\end{array}$ & 31.4 & 5.75 & 92 & 12 & Cytoplasm & Oxidative stress & Upregulated & $1.00: 4.42$ \\
\hline 63 & AAB63591 & Chaperonin $10 \mathrm{Kd}$ subunit & 25.8 & 5.66 & 82 & 8 & Cytoplasm & Protein stabilization & Upregulated & 1.00:3.54 \\
\hline
\end{tabular}

S.N. = Spot number, Exp. Mw = Experimental molecular weight; Exp. Pi = Experimental isoelectric point; M.S. = Mascot score. PDQuest software was used for spot volume analysis. The fold change of up-regulated protein spot volumes was calculated by treatment/optimum, whereas the change fold of downregulated protein spot volumes was calculated by optimum/treatment. The relative spot intensity of proteins was shown in fold changes between optimum-P and low-P. Kd = Kilo-Dolton; STMs = Signal transduction mechanisms. 


\section{Discussion}

The performance of P-inefficient cultivar (cv. Nagina 22) and P-efficient cultivar (cv. Panvel) in terms of morphological traits, like plant height, plant biomass, and $\mathrm{P}$ concentration in shoot and root, showed that cv. Nagina 22 was more affected than cv. Panvel by low P treatment. The plant biomass was low in the cv. Nagina 22 than the cv. Panvel even at optimum-P, which may be due to the expression differences of some proteins. The PUE of the latter is higher than the former cultivar. Based on these observations, it can be revealed that there is genetic variability in these rice cultivars in response to low $\mathrm{P}$ condition. The $\mathrm{cv}$. Panvel has a better adaptive response to $\mathrm{P}$ deficiency than cv. Nagina 22. Earlier studies have also reported the genetic variability in the rice genotypes in response to $\mathrm{P}$ deficiency $[27,28]$. Phosphorus deficiency affected many metabolic processes that led to a decrease in the biomass accumulation and overall growth of the plants. Some rice genotypes develop an adaptive mechanism to tolerate $P$ deficiency stress to some extent through modification in the root architecture [29], and changes in the expression level of enzymes of key metabolic pathways. The reduction in the activities of the enzyme of the Calvin cycle in the leaves of rice by $\mathrm{P}$ deficiency has been reported [9]. Changed activities of the enzymes of carbon metabolism, nitrogen metabolism, and energy metabolism have been observed in the leaves of rice when the supply of P was altered [10]. It is suggested that a well sophisticated regulatory network of genes in plants control the nutrient homeostasis through differential expression of proteins. A proteomics approach was used in the present study to investigate the proteins involved in the adaptive response of the P-efficient and P-inefficient rice cultivars to $P$ deficiency. Previous studies on the proteomics of rice, maize, oilseed rape, and Arabidopsis under P deficiency are limited to the expression pattern of the proteins of root only $[12,15,17,30]$. However, the assimilation and utilization of $\mathrm{P}$ in the key metabolic processes take place in the leaves of the plants. Therefore, the leaf proteome profiles of contrasting P-efficient rice cultivars were analyzed in this study under low P and optimum P conditions. The cv. Nagina 22 is fully sequenced and cv. Panvel is not fully sequenced at the genomic level, and of both the cultivars belong to two different subspecies (Aus and Indica) of rice due to which there was little difference in sequences of the identified proteins. Comparative analysis of the leaf proteome of the P-efficient and P-inefficient rice cultivars provided a better way for the identification of the $\mathrm{P}$ deficiency adaptive proteins in rice. The identified differentially expressed proteins (DEPs) of this study were discussed with their functions in their respective pathways. Most of the DEPs were involved in photosynthesis, where these proteins affect light and dark reactions of the photosynthesis process. Some DEPs were involved in oxidative stress and defense pathways, which help plants to tolerate P stress, and few DEPs were related to protein synthesis, where they either have an impact on translation or protein stabilization. Other DEPs were involved in Kreb's cycle, sucrose metabolism, Embden-Mayerhoff and Hexose Monophosphate pathways. Figure 3 shows the schematic model of organized mechanisms of adaptation to P deficiency in P-efficient rice cultivar (cv. Panvel). 


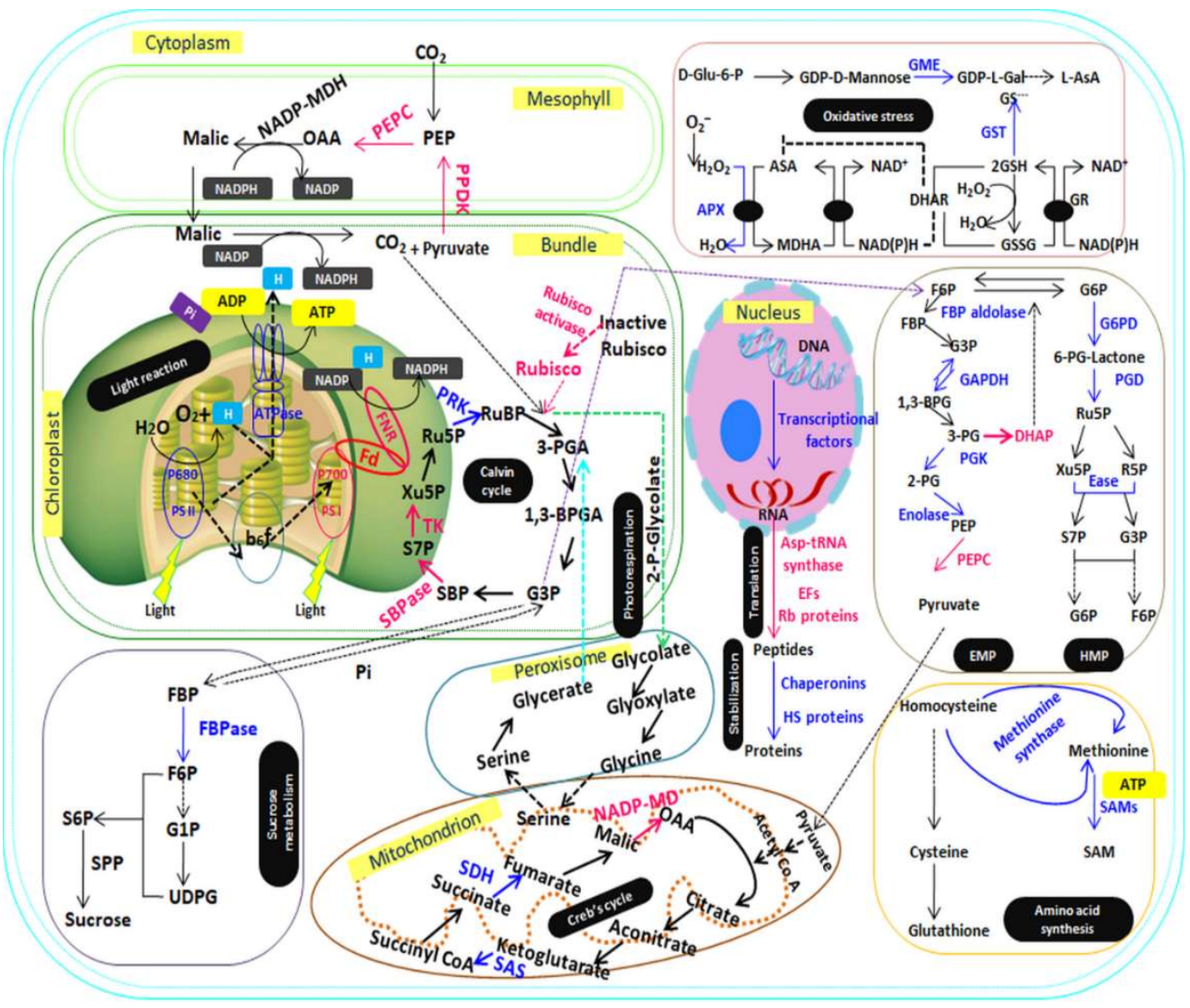

Figure 3. Schematic model of organized mechanisms of adaptation to P deficiency in P-efficient rice cultivar. Identified proteins were portrayed into subcellular location according to their molecular and metabolic pathways. Protein expression patterns were indicated by marking protein names and arrows in blue (upregulated) or pink (downregulated). 1,3-BPG: 1,3-bisphosphoglycerate; 1,3-BPGA: 1,3-bisphosphoglycerate; 2PG: 2-phosphoglycerate; 3PG: 3-phosphoglycerate; 3-PGA: 3-phosphoglycerate; 6-PG-lactone: 6-phosphoglucono-lactone; ADP: adenosine diphosphate; APX: ascorbate peroxidase; ASA: ascorbic acid; ASP: aspartic acid; ATP: adenosine triphosphate; D-Glu6P: D-Glucose 6-phosphate; DHAP: dihydroacetone phosphate; DHAR: dehydroascorbate reductase; EF: elongation factors; EMP: Embden-Meyerhof-Parnas pathway; F6P: fructose-6-phosphate; FBP aldose: fructose-1,6-bisphosphate aldose; FBP: fructose-1,6-bisphosphate; FBPase: fructose-1,6-bisphosphatase; Fd: ferredoxin; FNR: ferredoxin-NADP reductase; G1P: glucose-1-phosphate; G3P: glyceraldehyde-3-phosphate; G6P: glucose-6-phosphate; G6PD: glucose-6-phosphate dehydrogenase; GAPDH: glyceraldehyde-3-phosphate dehydrogenase; GDP-L-Gal: GDP-L-galactose; GME: GDP-D-mannose-3,5-epimerase; GR: glutathione reductase; GSH: reduced glutathione; GSSG: oxidized glutathione; GST: glutathione-S-transferase; HMP: hexose-monophophate-pathway; HS proteins: heat shock proteins; MDHA: monodehydroasorbate; NADP-MDH: NADP-malate dehydrogenase; OAA: oxalacetic acid; PEP: phosphoenolpyruvate; PEPC: phosphoenolpyruvate carboxylase; PEPC: phosphoenolpyruvate carboxylase;PGD: phosphogluconate dehydrogenase; PGK: phosphoglycerate kinase; PPDK: pyruvate orthophosphate dikinase; PRK: phosphoribolokinase; PS I: photosystem I; PS II: photosystem II; R5P: ribose-5-phosphate; RB proteins: ribosomal proteins; Ru5P: ribulose-5-phosphate; Rubisco: ribose 1,5-bisphosphate carboxylase/oxygenase; RuBP: ribulose-1,5-diphosphate; S6P: sucrose-6-phosphate; S7P: 7-phosphosedoheptose; SAMs: S-adenosymethionine synthase; SAS: succinyl-CoA-synthetase; SBP: sedoheptulose-1,7-bisphosphate; SDH: succinate dehydrogenase; SPP: sucrose-6-phosphate phosphohydrolase; TCA cycle: tricarboxylic acid cycle; TK: transketolase; UDPG: uridine diphosphoglucose; Xu5P: xylulose-5-phosphate.The source of the pathways, Calvin cycle, protein synthesis, oxidative stress and EMP pathway [15], and for light reaction, Creb's cycle, sucrose metabolism and HMP pathway [30]. 


\subsection{Expression Pattern of the Proteins of Energy Metabolism under P-deprivation}

Modifications in P and energy metabolism under P-starvation greatly affect the plant physiology. Phosphorus deficiency affects the proteins that are involved in electron transport and glycolytic enzymes. Remobilization of inorganic phosphate from different substrates is due to the scavenging allocation of enzymes by internal P sources, such as phospholipases, nucleases, and phosphatases [31]. Plants need to maintain the $\mathrm{P}$ homeostasis to release the stress under low-P conditions. In this experiment, the PUE was low in both the cultivars under low-P conditions by the difference in expression of some proteins which may be directly or indirectly involved in PUE in the plants. Our study depicted diversified expression results concerning PUE and energy metabolism under low-P conditions. Phosphogluconate dehydrogenase (PGDH, five protein families) in cv. Panvel may regulate carboxylation reactions by functioning on the precursor of ribulose 1,5-bisphosphate (RuBP, 11 proteins, and seven protein family) as a carboxylation/Rubisco substrate and, hence, may replace Rubisco with its reversible reductive carboxylase activity [32]. While the upregulation of fructose-1,6-bisphosphate in both of the cultivars showed that there is an enhancement in carbon fixation, the upregulation of sedoheptulose-1,7-bisphosphatase (BiBPase) in cv. Panvel only revealed that it redirects the carbon in coordination with aldolase that functions as the rate-limiting enzyme in the Calvin cycle [33]. The upregulation of phosphoglycerate kinases and 6-phosphogluconolactonase in cv. Panvel suppressed more $\mathrm{CO}_{2}$ assimilation and starch degradation under P-deficient conditions in a process to save energy [34]. These proteins can be assumed to be candidate $\mathrm{P}$ deficiency adaptive proteins of rice. Succinate dehydrogenase (SDH) and succinyl-CoA synthetase function in the tricarboxylic acid cycle and their upregulation in cultivar cv. Panvel under P deficient conditions suggested that there is an enhancement in the fumarate formation from succinate, and the production of GTPs (Guanosine-5'-triphosphate) [35,36]. Glyceraldehyde-3-phosphate dehydrogenase (GAPDH, 20 proteins, and 16 protein family) was upregulated in cv. Panvel. It plays an active part by redirecting energy fluxes and improving biomass production according to nutrient availability [37]. An intermediate enzyme of the glycolytic pathway enolase 1 was upregulated in both the cultivars. It catalyzes the conversion of 2-phosphoglycerate (2-PGA) to phosphoenolpyruvate (PEP) in plastid [38]. The differential expression pattern of proteins of energy metabolism and $\mathrm{P}$ homeostasis in cv. Panvel and cv. Nagina 22 under low P conditions showed that the P-efficient cultivar of rice managed the expression of these proteins in a more efficient way than the P-inefficient cultivar in order to adapt to $\mathrm{P}$ deficiency to some extent. The phenotypic traits, like plant dry weight and PUE, have shown strong cultivar $\times$ treatment interaction, which also suggests that there is a difference in protein expression between the rice cultivars.

\subsection{Expression Pattern of the Proteins Involved in Transcription and Translation}

The down-regulation of RNA polymerase $\beta$ chain and Integrin-linked protein kinase family protein in cv. Nagina 22 suggested that there was a reduction in the translation process under low-P condition. The expression of these transcriptional factors has a significant impact on biomass and $\mathrm{P}$ content in rice, as reported earlier, the role of OsPTF1 under P-deficient condition in rice [39]. The 14 " C3 $" \mathrm{C} 3$ protein is involved in cellular regulatory pathways for signal transduction, metabolism. Its differential expression functions as an activator/repressor with phosphorylation of target proteins [40]. This upregulation of this protein in cv. Panvel suggested that this protein can help in the regulation of $P$ deficiency stress stimuli and defense signaling factors in P-efficient cultivar.

The involvement of $\mathrm{P}$ in energy metabolism and transcription process, and as a component of nucleic acids, suggested that $P$ can affect some steps of the protein synthesis [41]. One of the limiting factors of protein synthesis is elongation factor-Tu (EF-Tu, seven proteins). It was downregulated in both the rice cultivars under low $\mathrm{P}$ condition. The EF-Tu helps in the binding of aminoacyl-tRNAs to the ribosome sub-unit and refolding of denatured proteins [42], thus playing a role of chaperone activity. Asparaginyl-tRNA synthetase (APRS) is the class II enzyme of aminoacyl-tRNA synthetases (AARS, only one protein) enzyme family with ubiquitous function and helps in the translation of 
mRNA codons into their corresponding amino acids [43]. It was down regulated in cultivar cv. Nagina 22 in low $\mathrm{P}$ condition. A group of ribosomal proteins was downregulated in both rice cultivars under low $\mathrm{P}$ condition. These are ribosomal protein $\mathrm{L} 23$ and ribosomal protein S4. Interestingly, the ribosomal protein S19 was downregulated in cv. Panvel only. The differential expression of ribosomal proteins was reported in response to abiotic stress [44]. It has been suggested that these proteins regulate the mechanism of protein synthesis by recognition of mRNA [45]. The differential expression pattern of the proteins that are involved in the transcription and translation processes under low $\mathrm{P}$ conditions in rice cultivars showed that there was a higher down-regulation of these proteins in cv. Nagina 22 than $\mathrm{cv}$. Panvel, suggesting that cv. Panvel developed an adaptive mechanism of maintaining the protein synthesis at a normal level to some extent under low P stress conditions.

\subsection{Photosynthesis and $\mathrm{CO}_{2}$ Regulation under P-deficiency}

The photosynthesis process comprises two parts, light reactions to produce ATP and NADPH in the thylakoid membrane and fixing of $\mathrm{CO}_{2}$ into organic molecules with the use of ATP and NADPH in the light-independent carbon reactions [46]. The downregulation of light-harvesting complex I (LHC, 29 proteins, and 19 protein family) in cv. Nagina 22 under low P condition showed the lesser capacity of this cultivar for low light absorption and light utilization by photosystem I (PSI) than cv. Panvel. Similar findings of reduction in light absorption along with oxygen-evolving complex proteins with a decrease of LHCs and chlorophyll content were observed under other stresses earlier [47]. Moreover, proteins that are involved in light energy transfer in photosynthesis, like ferredoxin, ferredoxin reductase (FNR, 12 proteins, and nine protein family), and beta and gamma subunit of ATP synthase (27 proteins and six protein family) were also down-regulated in cultivar cv. Nagina 22 under low $\mathrm{P}$ condition. The above-mentioned proteins are helpful in the production in NADPH and ATP [48,49]. The down-regulation of these proteins reduced the photosynthetic efficiency of cv. Nagina 22 under low P condition.

Expressions of the proteins that were involved in the dark reaction of photosynthesis were also down-regulated in P-inefficient rice cultivar (cv. Nagina 22). These proteins are ribulose-1, 5-bisphosphate carboxylase/oxygenase (Rubisco, five-member family, OsRBCS1-OsRBCS5), Rubisco activase (RCA, three proteins belong to AAA + superfamily), phosphoglycerate kinase (PGK, 20 proteins and seven protein family)), and transketolase. Rubisco is a rate-limiting enzyme of $\mathrm{CO}_{2}$ fixation [50], which is activated by an ATP-dependent enzyme Rubisco activase [51]. The downregulation of transketolase coincided with previous findings under stress conditions in tobacco and rice $[52,53]$. These findings demonstrated the repression of ribulose-1, 5-biphosphate regeneration, and photosynthesis (Figure 4). Other proteins that were involved in $\mathrm{CO}_{2}$ fixation were also differentially expressed under low $\mathrm{P}$ conditions in rice cultivars. These were phosphoenolpyruvate carboxylase (PEPC), NADP-malate dehydrogenase (NADP-MDH), and pyruvate orthophosphate dikinase (PPDK). The PEPC helps in the $\mathrm{CO}_{2}$ fixation by bicarbonate formation and it regulates the photo-respiratory pathway. This protein was downregulated in cv. Nagina 22 under low P conditions, but upregulated in cv. Panvel, which suggested P deficiency adaptive mechanism and involves the photosystem II functioning and its structural stability $[54,55]$.

\subsection{Expression Proteins of Antioxidant Defense System under P-deficiency}

The generation of ROS (reactive oxygen species) is due to abiotic stress that has a negative impact on plants, as it oxidizes life-sustaining biomolecules, like proteins, lipids, carbohydrates, and nucleic acids. The upregulation of glutathione S-transferases (GSTs) in both the rice cultivars at low P conditions suggested that low $\mathrm{P}$ condition causes oxidative stress also through the generation of ROS. Ascorbate peroxidase was upregulated in cultivar cv. Nagina 22, which has multifunction towards ROS depletion, like scavenging $\mathrm{H}_{2} \mathrm{O}_{2}$. Its overexpression enhances stress tolerance in plants [56]. The upregulation of glyoxylase I7 in both the cultivars and upregulation of 59-epimerase only in cv. Panvel under low-P condition suggested that the expression antioxidative defense system of cv. Panvel is 
better than cv. Nagina 22. These proteins are involved in the biosynthesis of ascorbic acid, which enhances stress tolerance in plants [57]. The chaperones (Chaperonin $60 \beta$ precursor and heat shock protein) have functions in intracellular protein folding and act as intercellular signals with a wide variety of biological effects. The Chaperonin $60 \beta$ has been found to be a pathogenic factor in a wide range of diseases [58]. These proteins were upregulated in cv. Panvel. A stress response protein, peptidyl-prolyl cis, trans-isomerase was upregulated in cv. Nagina 22. This protein has an important role in better survival and tolerance to stress conditions [59]. The PR-10 protein (pathogenesis-related protein) was upregulated in cultivar cv. Panvel and plays a role in the defense mechanisms for plant tolerance against pathogen attack and abiotic stimuli [60]. Differential expression patterns of the proteins of the antioxidant defense system in cv. Panvel and cv. Nagina 22 suggested that this system is also involved in the $\mathrm{P}$ deficiency adaptation mechanism of rice. Plants undertake some changes to tolerate the stress conditions, like decreasing ROS production by enhancing antioxidant defense or change in root architecture, like increasing root length, which was revealed under the low-P condition in the study. Most of the DEPs are responsive to P-deficiency because of their expression changes under low-P conditions, and some of the responsive proteins, like transcriptional factors and antioxidants, are directly involved in stability and tolerance mechanisms, which enable plants to tolerant P-deficiency.

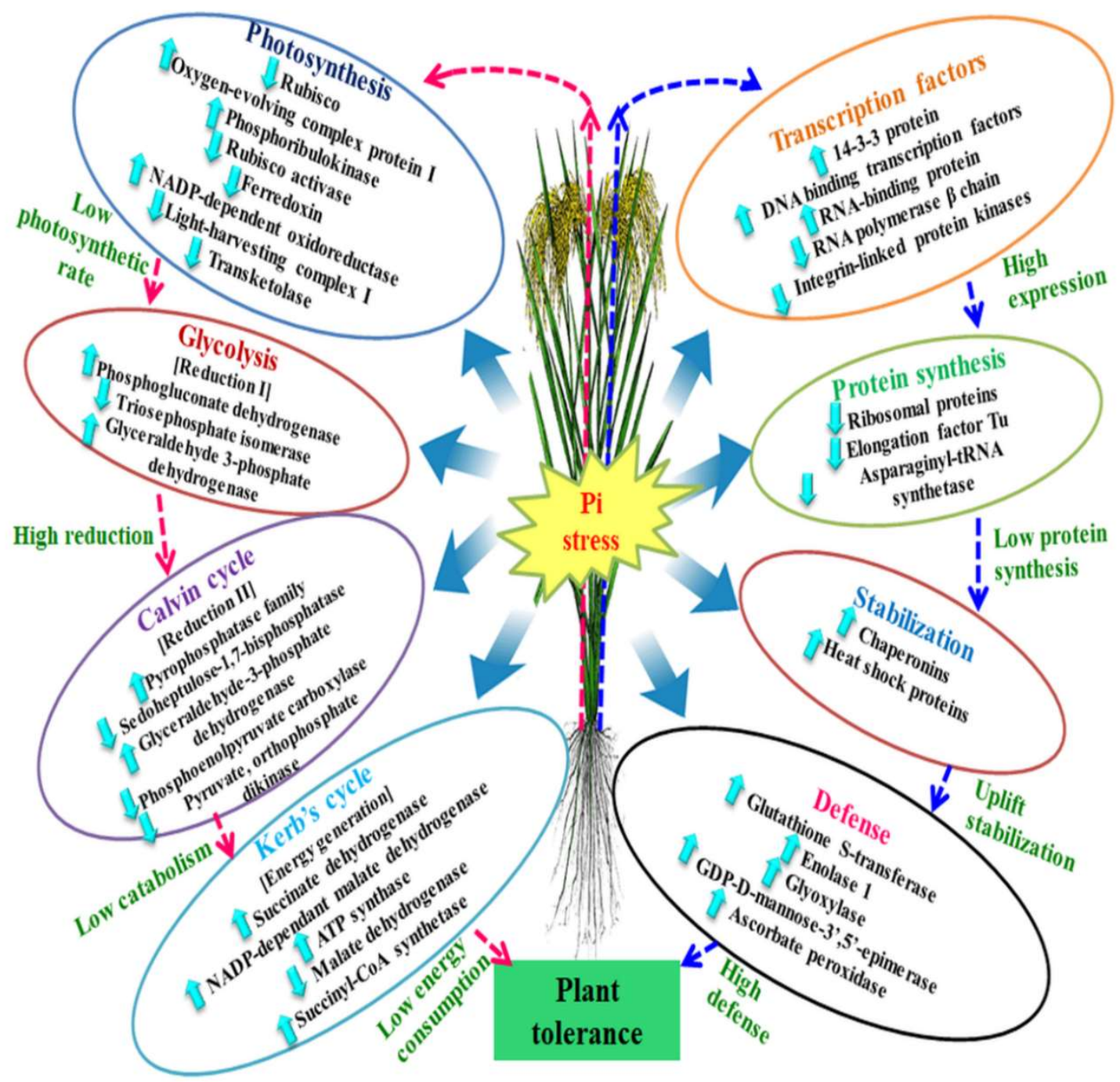

Figure 4. Representation of differentially expressed proteins and their alliance with the biological processes under low phosphorus. In the right side of the figure, the arrows with blue colour depict modulation of molecular factors to raise the defense level. Whereas, left side arrows with pink colour shows the regulation of low energy consumption under phosphorus stress. $\mathrm{Pi}=$ Inorganic Phosphorus 


\section{Conclusions}

The leaf proteome profile of the P-efficient and P-inefficient cultivars of rice suggested that P-efficient rice cultivar developed a P-deficiency adaptive mechanism through the change in the expression pattern of the proteins that are involved in energy metabolism, photosynthesis, and $\mathrm{CO}_{2}$ assimilation. Rubisco activase, phosphoenolpyruvate carboxylase, F1-ATP synthase, chloroplast light-harvesting complex I protein, and glyceraldehyde 3-phosphate dehydrogenase are potential $\mathrm{P}$ deficiency adaptive protein candidates. The regulation of these proteins can improve the tolerance of rice under P starvation. The upregulation of antioxidant enzymes (like glyoxylase I7, 5' -epimerase and Ascorbate peroxidase) and defense proteins (like pyrroline-5-carboxylate synthetase) suggested that $P$ deficiency creates oxidative stress, and the P-efficient cultivar of rice developed stronger protection from ROS accumulation damage than P-inefficient cultivar under low $\mathrm{P}$ condition. The information on the differential expression pattern of proteins of P-efficient and P-inefficient rice cultivars under low $\mathrm{P}$ condition will help develop strategies for generating rice with high PUE.

Supplementary Materials: The following are available online at http://www.mdpi.com/2073-4395/10/7/1028/s1, Figure S1. Plants of 30-days-old rice cultivars, Nagina 22 and Panvel, grown under optimum-P (A, C) and low-P $(\mathrm{B}, \mathrm{D})$ conditions.

Author Contributions: Conceptualization, A.Y.T. and A.A.; methodology, A.Y.T. and A.A.; software, A.Y.T., H.M.A. and A.A.; validation, A.Y.T., H.M.A. and A.A.; formal analysis, A.Y.T. and A.A.; investigation, A.Y.T., H.M.A. and A.A.; resources, H.M.A. and A.A.; data analysis, A.Y.T., H.M.A.; writing-original draft preparation, A.Y.T., and A.A.; writing-review and editing, A.Y.T., H.M.A. and A.A.; supervision, A.A.; project administration, H.M.A. and A.A.; funding acquisition, H.M.A. and A.A. All authors have read and agreed to the published version of the manuscript.

Funding: This research received no external funding.

Acknowledgments: The authors would like to extend their sincere appreciation to the King Saud University, Riyadh, Saudi Arabia for its support to the Researchers Supporting Project number (RSP-2020/123).

Conflicts of Interest: The authors declare no conflict of interest.

\section{Abbreviations}

$\begin{array}{ll}\text { PUE } & \text { Phosphate utilization efficiency } \\ \text { 2DE } & \text { Two-dimensional gel electrophoresis } \\ \text { DEP } & \text { Differentially expressed proteins } \\ \text { MALDI-TOF } & \text { Matrix-assisted laser desorption/ionization-time of flight }\end{array}$

\section{References}

1. Fischer, R.A.; Edmeades, G.O. Breeding and Cereal Yield Progress. Crop. Sci. 2010, 50, S-85-S-98. [CrossRef]

2. Lynch, J.P. Root Phenes for Enhanced Soil Exploration and Phosphorus Acquisition: Tools for Future Crops. Plant Physiol. 2011, 156, 1041-1049. [CrossRef] [PubMed]

3. Doberman, A.; Fairhurst, T. Rice: Nutrient Disorders and Nutrient Management; IRRI \& PPI \& PPIC: Makati, Philippines; Singapore, 2000.

4. Heuer, S.; Gaxiola, R.; Schilling, R.; Herrera-Estrella, L.; López-Arredondo, D.; Wissuwa, M.; Delhaize, E.; Rouached, H. Improving phosphorus use efficiency: A complex trait with emerging opportunities. Plant J. 2017, 90, 868-885. [CrossRef] [PubMed]

5. Van Kauwenbergh, S.J. World Phosphate Rock Reserves and Resources; IFDC: Muscle Shoals, AL, USA, 2010.

6. Dawe, D. The potential role of biological nitrogen fixation in meeting future demand for rice and fertilizer. In The Quest for Nitrogen Fixation in Rice; Ladha, J.K., Reddy, P.M., Eds.; International Rice Research Institute: Los Banos, Philippines, 2000; pp. 93-118.

7. Van Der Velde, M.; Folberth, C.; Balkovič, J.; Ciais, P.; Fritz, S.; Janssens, I.A.; Obersteiner, M.; See, L.; Skalský, R.; Xiong, W.; et al. African crop yield reductions due to increasingly unbalanced Nitrogen and Phosphorus consumption. Glob. Chang. Boil. 2014, 20, 1278-1288. [CrossRef]

8. Chiera, J.; Thomas, J.; Rufty, T.W. Leaf initiation and development in soybean under phosphorus stress. J. Exp. Bot. 2002, 53, 473-481. [CrossRef] 
9. Brooks, A. Effects of Phosphorus Nutrition on Ribulose-1, 5-Bisphosphate Carboxylase Activation, Photosynthetic Quantum Yield and Amounts of Some Calvin-Cycle Metabolites in Spinach Leaves. Funct. Plant Boil. 1986, 13, 221. [CrossRef]

10. Tang, X.R.; Yu, T.Q. Effects and mechanisms of $\mathrm{P}$ and $\mathrm{K}$ nutrients on yield and protein content of fodder rice. Agric. Sci. China 2002, 1, 432-437.

11. Qiu, H.; Liu, C.; Yu, T.; Mei, X.; Wang, G.; Wang, J.; Cai, Y. Identification of QTL for acid phosphatase activity in root and rhizosphere soil of maize under low phosphorus stress. Euphytica 2014, 197, 133-143. [CrossRef]

12. Jiang, H.; Zhang, J.; Han, Z.; Yang, J.; Ge, C.; Wu, Q. Revealing new insights into different phosphorus-starving responses between two maize (Zea mays) inbred lines by transcriptomic and proteomic studies. Sci. Rep. 2017, 7, 44294. [CrossRef]

13. Ganie, A.H.; Ahmad, A.; Pandey, R.; Aref, I.M.; Yousuf, P.Y.; Ahmad, S.; Iqbal, M. Metabolite Profiling of Low-P Tolerant and Low-P Sensitive Maize Genotypes under Phosphorus Starvation and Restoration Conditions. PLoS ONE 2015, 10, e0129520. [CrossRef] [PubMed]

14. Huang, G.; Liang, W.; Sturrock, C.J.; Pandey, B.K.; Giri, J.; Mairhofer, S.; Wang, D.; Müller, L.; Tan, H.; York, L.M.; et al. Rice actin binding protein RMD controls crown root angle in response to external phosphate. Nat. Commun. 2018, 9, 2346. [CrossRef]

15. Alexova, R.; Millar, A.H. Proteomics of phosphate use and deprivation in plants. Proteomics 2013, 13, 609-623. [CrossRef] [PubMed]

16. Kim, S.G.; Wang, Y.; Lee, C.H.; Mun, B.G.; Kim, P.J.; Lee, S.Y.; Kim, Y.C.; Kang, K.Y.; Rakwal, R.; Agrawal, G.K.; et al. A comparative proteomics survey of proteins responsive to phosphorous starvation in roots of hydroponically-grown rice seedlings. J. Korean Soc. Appl. Biol. 2011, 54, 667-677. [CrossRef]

17. Torabi, S.; Wissuwa, M.; Heidari, M.; Naghavi, M.R.; Gilany, K.; Hajirezaei, M.-R.; Omidi, M.; Yazdi-Samadi, B.; Ismail, A.M.; Salekdeh, G.H. A comparative proteome approach to decipher the mechanism of rice adaptation to phosphorous deficiency. Proteomics 2009, 9, 159-170. [CrossRef] [PubMed]

18. Yoshida, S. Routine Procedure for Growing Rice Plants in Culture Solution. In Laboratory Manual for Physiological Studies of Rice; Yoshida, S., Forno, D.A., Cock, J.H., Eds.; International Rice Research Institute: Los Banos, Philippines, 1976; pp. 61-66.

19. Wu, C.; Wang, Q.; Xue, S.; Pan, W.; Lou, L.; Li, D.; Hartley, W. Do aeration conditions affect arsenic and phosphate accumulation and phosphate transporter expression in rice (Oryza sativa L.)? Environ. Sci. Pollut. Res. 2016, 25, 43-51. [CrossRef] [PubMed]

20. Mahajan, G.; Pandey, R.N.; Sahoo, R.N.; Gupta, V.K.; Datta, S.C.; Kumar, D. Monitoring nitrogen, phosphorus and sulphur in hybrid rice (Oryza sativa L.) using hyperspectral remote sensing. Precis. Agric. 2016, 18, 736-761. [CrossRef]

21. Syers, J.K.; Johnston, A.E.; Curtin, D. Efficiency of soil and fertilizer phosphorus use. FAO Fertil. Plant Nutr. Bull. 2008, 18, 108.

22. Isaacson, T.; Damasceno, C.M.B.; Saravanan, R.S.; He, Y.; Catalá, C.; Saladié, M.; Rose, J.K.C. Sample extraction techniques for enhanced proteomic analysis of plant tissues. Nat. Protoc. 2006, 1, 769-774. [CrossRef]

23. O'Farrell, P.H. High resolution two-dimensional electrophoresis of proteins. J. Boil. Chem. 1975, 250, 4007-4021.

24. Wheeler, D.L.; Barrett, T.; Benson, D.A.; Bryant, S.H.; Canese, K.; Chetvernin, V.; Church, D.M.; DiCuccio, M.; Edgar, R.; Federhen, S.; et al. Database resources of the national center for biotechnology information. Nucleic Acids Res. 2006, 35, 5-12. [CrossRef]

25. Wu, C.H. The Universal Protein Resource (UniProt): An expanding universe of protein information. Nucleic Acids Res. 2006, 34, D187-D191. [CrossRef]

26. Guda, C. pTARGET: A web server for predicting protein subcellular localization. Nucleic Acids Res. 2006, 34, W210-W213. [CrossRef] [PubMed]

27. Chankaew, S.; Monkham, T.; Pinta, W.; Sanitchon, J.; Kaewpradit, W.; Srinives, P. Screening tolerance to phosphorus deficiency and validation of phosphorus pptake 1 (Pup1) gene linked markers in Thai indigenous upland rice germplasm. Agronomy 2019, 9, 81. [CrossRef]

28. Wissuwa, M.; Ae, N. Genotypic variation for tolerance to phosphorus deficiency in rice and the potential for its exploitation in rice improvement. Plant Breed. 2001, 120, 43-48. [CrossRef]

29. Vejchasarn, P.; Lynch, J.P.; Brown, K.M. Genetic Variability in Phosphorus Responses of Rice Root Phenotypes. Rice 2016, 9, 29. [CrossRef] 
30. Zhang, K.; Liu, H.; Tao, P.; Chen, H. Comparative Proteomic Analyses Provide New Insights into Low Phosphorus Stress Responses in Maize Leaves. PLoS ONE 2014, 9, e98215. [CrossRef]

31. Zhang, W.; Gruszewski, H.A.; Chevone, B.I.; Nessler, C.L. An Arabidopsis Purple Acid Phosphatase with Phytase Activity Increases Foliar Ascorbate1 [OA]. Plant Physiol. 2007, 146, 431-440. [CrossRef]

32. Bar-Even, A. Daring metabolic designs for enhanced plant carbon fixation. Plant Sci. 2018, 273, 71-83. [CrossRef] [PubMed]

33. De Porcellinis, A.J.; Nørgaard, H.; Brey, L.M.F.; Erstad, S.M.; Jones, P.R.; Heazlewood, J.L.; Sakuragi, Y. Overexpression of bifunctional fructose-1,6-bisphosphatase/sedoheptulose-1,7-bisphosphatase leads to enhanced photosynthesis and global reprogramming of carbon metabolism in Synechococcus sp. PCC 7002. Metab. Eng. 2018, 47, 170-183. [CrossRef] [PubMed]

34. Wang, Y.; Lu, Y.; Chang, Z.; Wang, S.; Ding, Y.; Ding, C. Transcriptomic analysis of field-grown rice (Oryza sativa L.) reveals responses to shade stress in reproductive stage. Plant Growth Regul. 2018, 84, 583-592. [CrossRef]

35. Huang, S.; Millar, A.H. Succinate dehydrogenase: The complex roles of a simple enzyme. Curr. Opin. Plant Boil. 2013, 16, 344-349. [CrossRef] [PubMed]

36. Belt, K.; Van Aken, O.; Murcha, M.; Millar, A.H.; Huang, S. An Assembly Factor Promotes Assembly of Flavinated SDH1 into the Succinate Dehydrogenase Complex. Plant Physiol. 2018, 177, 1439-1452. [CrossRef] [PubMed]

37. Scheibe, R. Maintaining homeostasis by controlled alternatives for energy distribution in plant cells under changing conditions of supply and demand. Photosynth. Res. 2018, 139, 81-91. [CrossRef] [PubMed]

38. Troncoso-Ponce, M.; Rivoal, J.; Dorion, S.; Sánchez, R.; Venegas-Calerón, M.; Moreno-Pérez, A.J.; Baud, S.; Garces, R.; Martínez-Force, E. Molecular and biochemical characterization of the sunflower (Helianthus annuus L.) cytosolic and plastidial enolases in relation to seed development. Plant Sci. 2018, 272, 117-130. [CrossRef] [PubMed]

39. Yi, K.; Wu, Z.; Zhou, J.; Du, L.; Guo, L.; Wu, Y.; Wu, P. OsPTF1, a Novel Transcription Factor Involved in Tolerance to Phosphate Starvation in Rice1 [w]. Plant Physiol. 2005, 138, 2087-2096. [CrossRef] [PubMed]

40. Chen, F.; Li, Q.; Sun, L.; He, Z. The Rice 14-3-3 Gene Family and its Involvement in Responses to Biotic and Abiotic Stress. DNA Res. 2006, 13, 53-63. [CrossRef] [PubMed]

41. Zörb, C.; Ludewig, U.; Hawkesford, M.J. Perspective on Wheat Yield and Quality with Reduced Nitrogen Supply. Trends Plant Sci. 2018, 23, 1029-1037. [CrossRef]

42. Kudlicki, W.; Coffman, A.; Kramer, G.; Hardesty, B. Renaturation of rhodanese by translational elongation factor (EF) Tu. Protein refolding by EF-Tu flexing. J. Boil. Chem. 1997, 272, 32206-32210. [CrossRef]

43. Yakobov, N.; Debard, S.; Fischer, F.; Senger, B.; Becker, H. Cytosolic aminoacyl-tRNA synthetases: Unanticipated relocations for unexpected functions. Biochim. Biophys. Acta (BBA)-Gene Regul. Mech. 2018, 1861, 387-400. [CrossRef]

44. Hummel, M.; Cordewener, J.H.; de Groot, J.C.; Smeekens, S.; America, A.H.; Hanson, J. Dynamic protein composition of Arabidopsis thaliana cytosolic ribosomes in response to sucrose feeding as revealed by label free MS E proteomics. Proteomics 2012, 12, 1024-1038. [CrossRef]

45. Graifer, D.M.; Karpova, G. Roles of ribosomal proteins in the functioning of translational machinery of eukaryotes. Biochimie 2015, 109, 1-17. [CrossRef] [PubMed]

46. Cardona, T.; Shao, S.; Nixon, P.J. Enhancing photosynthesis in plants: The light reactions. Essays Biochem. 2018, 62, 85-94. [CrossRef] [PubMed]

47. Dalal, V.K.; Tripathy, B.C. Water-stress induced downsizing of light-harvesting antenna complex protects developing rice seedlings from photo-oxidative damage. Sci. Rep. 2018, 8, 5955. [CrossRef] [PubMed]

48. Hashida, S.-N.; Miyagi, A.; Nishiyama, M.; Yoshida, K.; Hisabori, T.; Kawai-Yamada, M. Ferredoxin/thioredoxin system plays an important role in the chloroplastic NADP status of Arabidopsis. Plant J. 2018, 95, 947-960. [CrossRef] [PubMed]

49. Medrano, H.; Parry, M.A.J.; Socias, X.; Lawlor, D.W. Long term water stress inactivates Rubisco in subterranean clover. Ann. Appl. Boil. 1997, 131, 491-501. [CrossRef]

50. Yousuf, P.Y.; Abd Allah, E.F.; Nauman, M.; Asif, A.; Hashem, A.; Alqarawi, A.A.; Ahmad, A. Responsive Proteins in Wheat Cultivars with Contrasting Nitrogen Efficiencies under the Combined Stress of High Temperature and Low Nitrogen. Genes 2017, 8, 356. [CrossRef] 
51. Henkes, S.; Sonnewald, U.; Badur, R.; Flachmann, R.; Stitt, M. A small decrease of plastid transketolase activity in antisense tobacco transformants has dramatic effects on photosynthesis and phenylpropanoid metabolism. Plant Cell 2001, 13, 535-551. [CrossRef]

52. Kim, D.-W.; Rakwal, R.; Agrawal, G.K.; Jung, Y.-H.; Shibato, J.; Jwa, N.-S.; Iwahashi, Y.; Iwahashi, H.; Kim, D.H.; Shim, I.-S.; et al. A hydroponic rice seedling culture model system for investigating proteome of salt stress in rice leaf. Electrophoresis 2005, 26, 4521-4539. [CrossRef] [PubMed]

53. Yang, X.; Liu, D.; Tschaplinski, T.J.; Tuskan, G.A. Comparative genomics can provide new insights into the evolutionary mechanisms and gene function in CAM plants. J. Exp. Bot. 2019, 70, 6539-6547. [CrossRef]

54. Liu, X.; Dai, C.; Zhou, J.; Ren, C.; Li, X.; Zhang, C.; Zhang, J. Phosphoenolpyruvate carboxylase regulation in C4-PEPC -expressing transgenic rice during early responses to drought stress. Physiol. Plant. 2016, 159, 178-200. [CrossRef]

55. Zhang, Y.; Giuliani, R.; Zhang, Y.; Zhang, Y.; Araújo, W.L.; Wang, B.; Liu, P.; Sun, Q.; Cousins, A.; Edwards, G.; et al. Characterization of maize leaf pyruvate orthophosphate dikinase using high throughput sequencing. J. Integr. Plant Boil. 2018, 60, 670-690. [CrossRef]

56. Liu, F.; Huang, N.; Wang, L.; Ling, H.; Sun, T.; Ahmad, W.; Muhammad, K.; Guo, J.; Xu, L.; Gao, S.; et al. A Novel L-ascorbate Peroxidase 6 Gene, ScAPX6, Plays an Important Role in the Regulation of Response to Biotic and Abiotic Stresses in Sugarcane. Front. Plant Sci. 2018, 8, 2262. [CrossRef]

57. Tao, J.; Wu, H.; Li, Z.; Huang, C.; Xu, X. Molecular Evolution of GDP-D-Mannose Epimerase (GME), a Key Gene in Plant Ascorbic Acid Biosynthesis. Front. Plant Sci. 2018, 9, 9. [CrossRef] [PubMed]

58. Maguire, M.; Coates, A.R.M.; Henderson, B. Chaperonin 60 unfolds its secrets of cellular communication. Cell Stress Chaperones 2002, 7, 317-329. [CrossRef]

59. Alavilli, H.; Lee, H.; Park, M.; Yun, D.-J.; Lee, B.-H. Enhanced multiple stress tolerance in Arabidopsis by overexpression of the polar moss peptidyl prolyl isomerase FKBP12 gene. Plant Cell Rep. 2017, 37, 453-465. [CrossRef] [PubMed]

60. Jain, S.; Kumar, D.; Jain, M.; Chaudhary, P.; Deswal, R.; Sarin, N.B. Ectopic overexpression of a salt stress-induced pathogenesis-related class 10 protein (PR10) gene from peanut (Arachis hypogaea L.) affords broad spectrum abiotic stress tolerance in transgenic tobacco. Plant Cell Tissue Organ Cult. (PCTOC) 2011, 109, 19-31. [CrossRef] 